UNIVERSIDADE DE SÃO PAULO

FACULDADE DE ECONOMIA, ADMINISTRAÇÃO E CONTABILIDADE DEPARTAMENTO DE ADMINISTRAÇÃO PROGRAMA DE PÓS-GRADUAÇÃo EM ADMINISTRAÇÃO

CENÁRIOS DO FUTURO E CAPACIDADES DINÂMICAS: UM ESTUDO NO SETOR DE ETANOL

Antonio Thiago Benedete da Silva

Orientador: Prof. Dr. James Terence Coulter Wright

SÃO PAULO 
Prof. Dr. João Grandino Rodas

Reitor da Universidade de São Paulo

Prof. Dr. Carlos Roberto Azzoni

Diretor da Faculdade de Economia, Administração e Contabilidade

Prof. Dr. Adalberto Américo Fischmann

Chefe do Departamento de Administração

Prof. Dr. Lindolfo Galvão de Albuquerque

Coordenador do Programa de Pós-Graduação em Administração 


\section{CENÁRIOS DO FUTURO E CAPACIDADES DINÂMICAS: UM ESTUDO NO}

SETOR DE ETANOL

Dissertação de Mestrado apresentada ao Departamento de Administração da Faculdade de Economia, Administração e Contabilidade da Universidade de São Paulo como requisito para a obtenção do título de Mestre em Administração.

Orientador: Prof. Dr. James Terence Coulter Wright

SÃO PAULO 


\section{FICHA CATALOGRÁFICA}

Elaborada pela Seção de Processamento Técnico do SBD/FEA/USP

Silva, Antonio Thiago Benedete da

Cenários do futuro e capacidades dinâmicas: um estudo no setor de etanol / Antonio Thiago Benedete da Silva. - São Paulo, 2010.

$77 \mathrm{p}$.

Dissertação (Mestrado) - Universidade de São Paulo, 2010.

Orientador: James Terence Coulter Wright

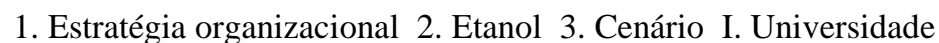
de São Paulo. Faculdade de Economia, Administração e Contabilidade. II. Título.

CDD - 658.401 
A minha mãe,Vilma, que por diversas vezes me deu a vida. 


\section{AGRADECIMENTOS}

A busca pelo conhecimento é uma jornada contínua; cada lugar aportado não é um destino findo, mas uma referência para um novo começo. No caminho, fundamental é cruzar com grandes Mestres e poder contar com o apoio daqueles que acreditam nos nossos sonhos mesmo nos momentos de incerteza e batalhas.

Inicialmente, meu muito obrigado ao Professor James Wright, pela abertura de portas, pelos desafios proporcionados e por estimular meu desenvolvimento.

Meu muito obrigado à Professora Flaviana Andrade de Pádua Carvalho, exemplo de pesquisadora, professora, profissional e pessoa ética, referência para mim durante toda a minha graduação na Universidade Federal de Lavras. Suas contribuições para a minha formação nunca serão esquecidas.

À minha família especial que continuamente dá lições de amor incondicional uns pelos outros. Mãe, Xanda, Isa, Rafa, Tia Helena, Tia Ro, Caio, Dani, Gu e Má, com vocês viver é muito mais legal.

À querida amiga Priscila Rezende da Costa pelo companheirismo, apoio e proveitosas discussões sobre pesquisa e sobre a vida na UFLA, na FEA e espero que por toda a vida. Aos amigos do Programa de Educação Tutorial em Administração da UFLA - Josy, Gaio, Tarsila, Camila, Stefânia, Gabriel e Roberta - que ofereceram um ambiente de alto nível acadêmico, profissional e intelectual. A convivência com talentos ambiciosos e honestos como vocês foi fundamental para o meu crescimento.

Aos amigos Denis e Renato, companheiros da UFLA e pessoas brilhantes. Trabalhar com pessoas competentes como vocês foi um privilégio.

À minha amiga Mitie; sobre a qual palavras são redundantes.

Aos professores e funcionários da FEA USP.

Por fim, agradeço a vida - que sempre oferece um caminho. 
"A sabedoria não nos é dada; temos de descobri-la sozinhos, depois de fazer uma jornada que ninguém pode fazer por nós ou nos poupar de fazer". Marcel Proust 


\section{RESUMO}

Tendo como base o contexto da indústria de etanol que apresenta incertezas, oportunidades e ameaças, os preceitos teóricos da obtenção de vantagens competitivas sustentáveis a partir do desenvolvimento de capacidades dinâmicas e a análise de ambientes complexos e com a presença de incertezas por meio de cenários, este trabalho apresentou a seguinte questão de pesquisa: Quais são as implicações para o desenvolvimento de capacidades dinâmicas pelas destilarias brasileiras de possíveis cenários do mercado internacional de etanol em 2020? Para respondê-la foi realizado um estudo exploratório, em uma abordagem qualitativa e de natureza aplicada, o qual compreendeu duas etapas. Inicialmente foram elaborados cenários para o mercado internacional de etanol em 2020. Para tanto, utilizou-se o método de elaboração de cenários proposto por Wright e Spers (2006). Em seguida, foi realizada uma pesquisa de campo com uma empresa do setor de etanol, tendo em vista analisar a consistência dos cenários elaborados e explorar empiricamente o conceito de capacidades dinâmicas. Assim, foi realizado um estudo de caso com uma destilaria localizada em Jacarezinho - Paraná. Neste trabalho, o escopo dos cenários foi a configuração futura do mercado internacional de etanol. O horizonte de tempo foi 2020, uma vez que grande parte da regulamentação que indica expansão da demanda do mercado internacional baseia-se neste ano. Foram produzidos quatro cenários ("Etanol: um biocombustível comercialmente viável", "Etanol: a commodity energética global sustentável", "Etanol: foco no mercado interno", e "Etanol: uma commodity regional") que posteriormente foram submetidos à análise de consistência e indicação do mais provável pela empresa pesquisada neste estudo. Foi indicado como mais provável o cenário "Etanol: a commodity energética global sustentável". A partir do cenário mais provável, a empresa pesquisada indicou que, para o futuro, o desafio será desenvolver as capacidades dinâmicas necessárias para capturar as oportunidades e dois pontos importantes foram destacados pela empresa, e que vão de encontro ao segundo grupo de capacidades propostas por Teece (2007), principalmente no que se refere ao delineamento de modelos de negócios e desenvolvimento de ativos complementares. Conforme foi destacado pelo dirigente durante a entrevista, será necessário desenvolver um novo modelo de negócios para as usinas, pois essas são muito suscetíveis às oscilações de mercado de curto prazo, principalmente em relação ao preço do álcool, preço do açúcar, preço do petróleo e preço do milho. Há a necessidade de novas fontes de receita nos períodos de baixa no mercado. Além disso, a empresa enxerga como grande obstáculo para o futuro o desenvolvimento de infra-estrutura logística para a exportação.

Palavras-chave: etanol; cenários; capacidades dinâmicas. 


\begin{abstract}
Based on a context of the ethanol industry that presents uncertainties, opportunities and threats, on the theoretical background of obtaining sustainable competitive advantage through the development of dynamic capabilities and on the analysis of complex situations using scenarios, this study analyzed the following research question: What are the implications for the development of dynamic capabilities by Brazilian ethanol distilleries of possible scenarios of the global ethanol market in 2020? To answer this question an applied exploratory study was conducted with a qualitative approach. in two stages. Initially scenarios were developed for the international market in 2020, using the scenario development method proposed by Wright and Spers (2006). Next, a field research was conducted with a company in the ethanol industry in order to analyze the consistency of the scenarios developed and empirically explore the concept of dynamic capabilities. Thus, a case study was performed with a firm located in Jacarezinho - Paraná. In this work, the scope of the scenarios was the future state of the international market for ethanol. The time horizon is 2020, since much of the regulations indicates that expansion of demand in the international market is based on this year. It was produced four scenarios ("Ethanol: a commercially viable biofuel", "Ethanol: a sustainable global energy commodity", "Ethanol: focus on the domestic market," and "Ethanol: a regional commodity") that subsequently were analyzed for consistency and indicated the more likely by the company investigated in this study. It was indicated as the most likely scenario "Ethanol: a sustainable global energy commodity". From the most likely scenario, the company surveyed indicated that for the future, the challenge will be to develop the dynamic capabilities necessary to capture the opportunities and two important points were highlighted by the company, and are aligned with the second set of capabilities proposed by Teece (2007), especially with regard to the design of business models and development of complementary assets. As noted by the manager during the interview, it will need to develop a new business model for companies, because they are very susceptible to fluctuations in short-term market, especially with the price of alcohol, sugar prices, oil prices and price of corn. There is a need for new sources of revenue in periods of market declines. In addition, the company sees as an obstacle to the future the development of transport infrastructure for export.
\end{abstract}

Key words: ethanol; scenarios; dynamic capabilities. 


\section{SUMÁRIO}

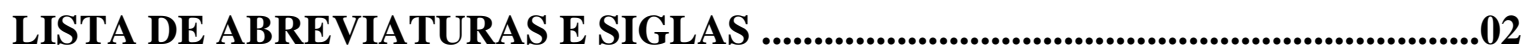

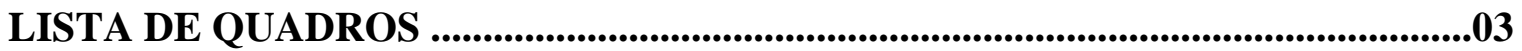

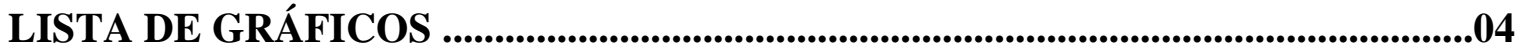

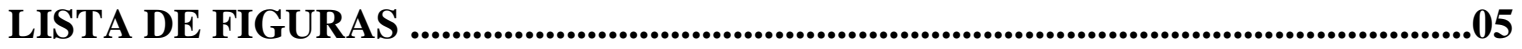

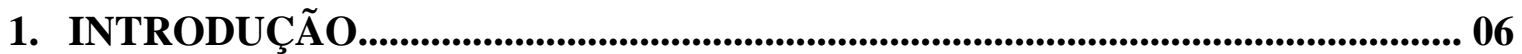

2. CONTEXTUALIZAÇÃO: BIOCOMBUSTÍVEIS E ETANOL.............................11

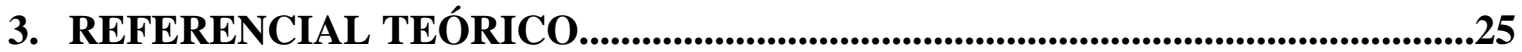

3.1 Capacidades Dinâmicas e Competitividade..........................................................25

3.2 Estudos Prospectivos e Cenários ………................................................................

4. PROCEDIMENTOS METODOLÓGICOS............................................................40

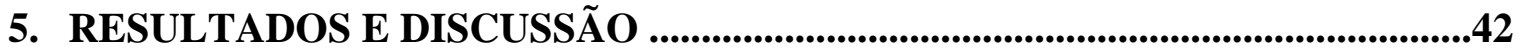

5.1 Mercado internacional de etanol em 2020 - UNICA ...........................................42

5.2 Desenvolvimento de cenários possíveis em 2020 .............................................47

5.3 Estudo empírico: aplicação dos cenários, atuação e capacidades dinâmicas ..........58

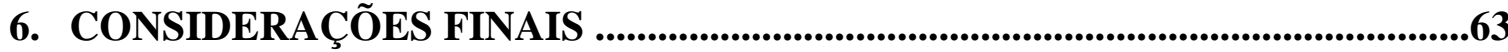

REFERÊNCIAS BIBLIOGRÁFICAS......................................................................65

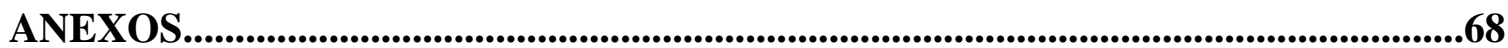




\section{LISTA DE ABREVIATURAS E SIGLAS}

BNDES - Banco Nacional de Desenvolvimento Econômico e Social

CBOT - Chicago Board of Trade

EPE - Empresa de Planejamento Energético

FAO - Food and Agriculture Organization

GEEs - Gases de efeito estufa

OCDE - Organização para Cooperação e Desenvolvimento Econômico

P\&D - Pesquisa e Desenvolvimento

UNICA - União da Indústria de Cana-de-Açúcar 


\section{LISTA DE QUADROS}

Quadro 1 - União Européia: cronologia dos biocombustíveis ............................................19

Quadro 2 - Setor sucroalcooleiro no Brasil ........................................................................20

Quadros 3 - Determinantes do aumento do preço dos alimentos .........................................23

Quadro 4 - Definições-chave de capacidades dinâmicas .........................................................26

Quadro 5 - Capacidades dinâmicas e dinamismo do mercado .................................................27

Quadro 6 - Capacidades dinâmicas e tipos de dinâmica dos mercados .................................28

Quadro 7 - Particularidades das categorias de fatores que identificam as capacidades dinâmicas de uma firma ............................................................................29

Quadro 8 - Microfundamentos das capacidades dinâmicas .....................................................30

Quadro 9 - Diferenças entre Previsão e Prospecção ............................................................... 31

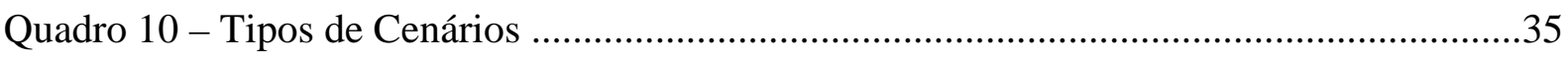

Quadro 11 - Métodos para elaboração de cenários ..................................................................36

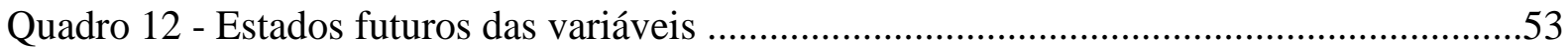

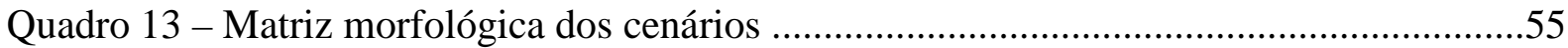




\section{LISTA DE GRÁFICOS}

Gráfico 1 - Produtividade média do etanol por área para diferentes culturas .........................15

Gráfico 2 - Custo de produção de etanol (US\$/galão) ..........................................................15

Gráfico 3 - Distribuição da produção mundial de etanol em 2006 .......................................16 


\section{LISTA DE FIGURAS}

Figura 1 - Rotas tecnológicas para produção de bioenergia ..................................................13

Figura 2 - Rotas tecnológicas para produção de etanol .........................................................14

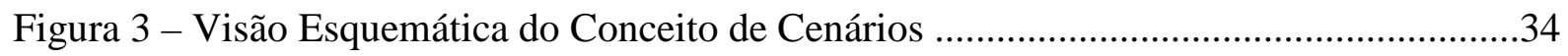

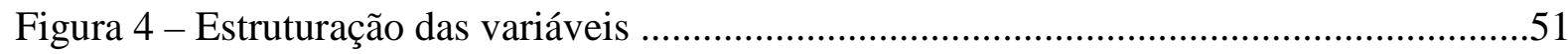




\section{INTRODUÇÃO}

Analisar a questão energética hoje, no mundo, requer a consideração de um conjunto de forças demográficas, sociais, econômicas, políticas e tecnológicas que estão modificando e dando novas formas para a sociedade e, portanto, criando desafios e lançando oportunidades para o desenvolvimento de soluções que possibilitem o bem-estar e o equilíbrio das nações.

Inovação, preocupações com o meio-ambiente e mudanças demográficas, sociais e econômicas associadas à emergência dos países em desenvolvimentos são apenas alguns fatores que podem ser mencionados como forças poderosas que já estão atuando na oferta e na demanda por fontes de energia.

Segundo Goldemberg e Moreira (2005), petróleo, gás natural e seus derivados representam 55\% do consumo mundial de energia para fins como uso em meios de transporte rápidos e eficientes e em boa parte das atividades industriais. Pontuam os autores que essas fontes não vão durar mais do que algumas décadas: como combustíveis fósseis, as suas reservas são finitas, a segurança de abastecimento é problemática para os muitos países que os importam e o seu uso é a principal fonte dos gases que estão provocando mudanças climáticas e o aquecimento global.

Alternativas para o suprimento de energia sempre foram buscadas. Entretanto, o que se observa hoje são preocupações que vão além da satisfação das necessidades humanas, e buscam olhar para o futuro do planeta, trazendo para o centro da discussão as fontes renováveis de energia. Para Costa e Prates (2005), energia renovável é uma expressão usada para descrever uma ampla gama de fontes de energia que são disponibilizadas na natureza de forma cíclica, dentre as quais pode-se destacar: a biomassa, a energia eólica, a energia solar, a energia de marés e pequenas centrais hidroelétricas. Para os autores é imprescindível que elas estejam inseridas nas políticas energéticas dos países, já que exercem um papel importante para a sustentabilidade do sistema energético.

Vários países têm investido na ampliação da participação das fontes renováveis de energia na matriz energética. O crescimento observado nos últimos anos é notável. Alinhada ao atual contexto global e inserida na questão energética mundial, no Brasil ganha relevância a discussão sobre os biocombustíveis, em especial o etanol. 
Estudo do Banco Nacional de Desenvolvimento Econômico e Social (BNDES, 2008) aponta que diversos países têm mostrado interesse no desenvolvimento da produção e no uso do etanol. Além de procurar cobrir suas próprias necessidades energéticas, em muitos casos busca-se constituir um mercado mundial para esse biocombustível, que aproxime países em condições de produzi-lo sustentavelmente do mercado de países potencialmente importadores, com vantagens para ambos. Na atualidade, tal mercado ainda é incipiente, mas as demandas crescentes por um combustível renovável e ambientalmente adequado, associadas ao potencial que o etanol de cana-de-açúcar apresenta para atender a critérios objetivos de sustentabilidade, sinalizam a existência de perspectivas interessantes (BNDES, 2008).

Segundo Milanez, Faveret Filho e Rosa (2008), a posição do Brasil no que se refere à produção de biocombustíveis pode ser classificada como privilegiada, em virtude da conjugação de dois fatores: a grande extensão territorial e o clima tropical. Isso é particularmente verdadeiro no que diz respeito à produção de etanol proveniente da cana-deaçúcar. O Brasil possui cerca de 100 milhões de hectares de terras aráveis distribuídas distantes dos biomas naturais - Amazônia, e, atualmente, o País utiliza apenas sete milhões de hectares para o plantio dessa cultura, sendo cerca de $50 \%$ para a produção de etanol e o restante para a de açúcar, representando apenas $1 \%$ do total utilizado para plantios, segundo dados da Empresa de Planejamento Energético (EPE, 2008).

O Brasil tem sido um dos maiores produtores mundiais de cana-de-açúcar ao longo da história. Em 1975, foi criado o Programa Nacional do Álcool - o Proálcool, com a finalidade de reduzir a grande dependência do petróleo importado e criar um mercado adicional para os produtores de açúcar, o que incentivou a indústria automobilística no desenvolvimento e fabricação de carros movidos exclusivamente a álcool (EPE, 2008).

Na primeira fase do Programa, o seu principal objetivo consistia na produção de álcool anidro para a mistura com gasolina. Esforços em Pesquisa e Desenvolvimento (P\&D) direcionados à fabricação de carros movidos exclusivamente a álcool resultaram na criação destes veículos em 1978 (EPE, 2008). Em decorrência ao segundo choque do petróleo em 1979, o governo brasileiro decidiu aumentar o uso combustível do etanol, assinando acordos com fabricantes de automóvel e estimulando a construção de um grande número de destilarias autônomas, o que deu início à produção em larga escala do etanol hidratado (EPE, 2008). 
O substancial crescimento das exportações de açúcar, na década de 1990, resultou em escassez e racionamento do etanol, comprometendo os objetivos originais do programa com o declínio do consumo deste combustível no Brasil que se estendeu até 2003. Neste ano, surge no mercado nacional o veículo flex-fuel ou bicombustível, cuja tecnologia permitia o uso de álcool hidratado ou gasolina, em qualquer proporção da mistura destes, possibilitando ao consumidor final a escolha do combustível para abastecer o seu automóvel (EPE, 2008).

Bastos (2007) pontua que programas da União Européia e dos Estados Unidos dedicam cada vez maior espaço ao etanol e, em especial, à utilização da biomassa como fonte de matériasprimas, com aporte de recursos para Pesquisa e Desenvolvimento de novas tecnologias e a aposta no desenvolvimento e na construção de biorrefinarias. As perspectivas de consolidação de seus mercados de etanol e alcance das metas de expansão do uso do etanol exigem a ampliação da produção em níveis não passíveis de serem atendidos. A ampliação da produção de etanol sem aumento da área cultivada requer o uso de fontes alternativas como a biomassa, que, ademais, poderá tornar o etanol competitivo em custos. Atualmente, isso não ocorre e há diferenças marcantes de custo dependendo da matéria-prima utilizada e dos processos de produção do etanol (BASTOS, 2007).

O surgimento e a movimentação de novos atores no mercado internacional de etanol podem representar um risco para a liderança brasileira no setor. Novas alternativas tecnológicas ao álcool produzido a partir de cana-de-açúcar têm sido apresentadas, a regulamentação para adição obrigatória à gasolina tem evoluído em diversos países, pressões para a instituição de um padrão e para a certificação dos biocombustíveis têm sido crescentes.

Nesse contexto, analisar o presente e prospectar o futuro é de fundamental importância para as destilarias brasileiras, identificando incertezas, oportunidades e ameaças, bem como pontos fortes e pontos fracos para, então, em uma perspectiva pró-ativa, identificar e desenvolver fontes sustentáveis de vantagem competitiva.

A literatura em administração estratégica tem apontado que fontes sustentáveis de vantagem competitiva são provenientes de um conjunto de capacidades que a organização desenvolve para renovar e reconfigurar seus ativos - tangíveis e intangíveis (TEECE, 2007; VOLBERDA, 2004; EISENHARDT; MARTIN, 2000; VASCOSCELOS; CYRINO, 2000; 
TEECE; PISANO; SHUEN, 1997). Tais capacidades receberam o nome de capacidades dinâmicas.

Segundo Teece, Pisano e Shuen (1997), em uma definição abrangente, capacidades dinâmicas são habilidades de atingir novas formas de vantagem competitiva. O termo "dinâmicas" refere-se à capacidade de renovar competências tendo em vista alcançar congruência com as mudanças no ambiente de negócios. O termo "capacidades" enfatiza o papel central da administração estratégica em adaptar, integrar e reconfigurar habilidades organizacionais internas e externas apropriadamente, bem como recursos e competências funcionais que vão de encontro às exigências do ambiente em mudança. Para os autores há três categorias de fatores que ajudam a identificar as capacidades dinâmicas de uma empresa: processos, posições e trajetórias. Processos gerenciais e organizacionais referem-se ao modo como as atividades são desenvolvidas na empresa, suas rotinas ou padrões de práticas correntes e aprendizagem; posição refere-se aos seus ativos específicos de tecnologia, propriedade intelectual, ativos complementares, base de clientes, e suas relações externas com fornecedores; e trajetória são as alternativas estratégicas disponíveis para a empresa, ou a presença ou ausência de retornos crescentes e dependências da trajetória (TEECE; PISANO; SHUEN, 1997).

Segundo Teece (2007), a extensão na qual a empresa desenvolve e emprega capacidades dinâmicas superiores determinarão a natureza e o montante de ativos que irão criar e o nível de lucro econômico que irão ganhar.

Para Vasconcelos e Cyrino (2000), a Teoria das Capacidades Dinâmicas elabora as idéias colocadas nas teorias dos processos de mercado e na teoria dos recursos (Resource Based View), tendo em vista formular uma teoria da formação das competências organizacionais em ambientes de alta complexidade e mudança. Segundo os autores, essa síntese teórica pretende acentuar os aspectos de co-evolução entre ambientes concorrenciais crescentemente complexos e as capacidades e os recursos das firmas.

Para abordar a evolução de ambientes complexos e marcados pela incerteza uma técnica possível é a elaboração de cenários. Wright e Spers (2006) afirmam que elaborar cenários não é um exercício de predição, mas sim um esforço de fazer descrições plausíveis e consistentes de situações futuras possíveis, apresentando os condicionantes do caminho entre a situação 
atual e cada cenário futuro, destacando os fatores relevantes às decisões que precisam ser tomadas. Fahey e Randall (1998) complementam afirmando que cenários são narrativas de projeções alternativas plausíveis de uma parte específica do futuro, oferecendo descrições contrastantes de como vários aspectos incertos do futuro podem se desenvolver.

Tendo como base o contexto da indústria de etanol que apresenta incertezas, oportunidades e ameaças, os preceitos teóricos da obtenção de vantagens competitivas sustentáveis a partir do desenvolvimento de capacidades dinâmicas e a análise de ambientes complexos e com a presença de incertezas por meio de cenários, este trabalho apresenta a seguinte questão de pesquisa:

Quais são as implicações para o desenvolvimento de capacidades dinâmicas pelas destilarias brasileiras de possíveis cenários do mercado internacional de etanol em 2020 ?

Para responder esta questão, os seguintes objetivos serão buscados:

- Descrever o cenário atual do mercado internacional de etanol;

- Elaborar quatro cenários futuros possíveis para o mercado internacional em 2020;

- Analisar empiricamente a consistência dos cenários e seus desdobramentos para o desenvolvimento de capacidades dinâmicas.

Para tanto, este trabalho está organizado em mais cinco seções, além desta Introdução - a qual apresentou o contexto, a questão de pesquisa, os objetivos e a justificativa do estudo. A seção 2 apresenta a contextualização do setor, mostrando os principais países produtores, os principais demandantes, as tecnologias atuais e em desenvolvimento, e aspectos do ambiente institucional que estão atuando para moldar o futuro. A seção 3 apresenta o referencial teórico onde são abordadas a teoria de capacidades dinâmicas e de cenários. A seção 4 apresenta os procedimentos metodológicos. A seção 5 apresenta os resultados, onde são desenvolvidos os cenários da pesquisa e o estudo empírico. Finalmente, a seção 6 apresenta as conclusões do estudo. 


\section{CONTEXTUALIZAÇÃO: BIOCOMBUSTÍVEIS E ETANOL}

Segundo Sachs (2005), os biocombustíveis estão atingindo maioridade, ou, pelo menos, assinalando uma situação nova, que se explica pela conjunção de três fatores:

1. Um número bastante grande de geólogos acredita que o pico da produção mundial de petróleo vai acontecer dentro de dez a vinte anos. Isso não significa que o petróleo vai desaparecer, mas que hoje, aparentemente, as novas reservas não compensam a extração, de modo que estamos instalados num período de esgotamento das reservas de petróleo que pode durar um século. Isso, todavia, não tem importância, e sim que estamos instalados de uma maneira duradoura em preços altos provocados por uma oferta que vai diminuir e uma demanda que continua, ainda, a aumentar. Esse é o primeiro fator, os preços do petróleo bateram os sessenta dólares o barril, muito acima daquilo que torna os biocombustíveis competitivos. E se trata de um fenômeno razoavelmente duradouro, estamos entrando numa nova época.

2. A segunda razão é geopolítica, ou seja, os custos cada vez maiores que os Estados Unidos e seus aliados têm na manutenção das linhas de abastecimento a partir do Médio Oriente. Há um número cada vez maior de especialistas norte-americanos que acha que é melhor investir nas alternativas do que continuar a administrar essa situação.

3. A terceira razão muito importante é o problema ambiental. Aí é evidente que mesmo que fosse realizado integralmente, o Protocolo de Kyoto ainda seria altamente insuficiente em termos da redução das emissões de gases de efeito estufa.

Em linha semelhante, Goldemberg e Moreira (2005) afirmam que petróleo, gás natural e seus derivados representam 55\% do consumo mundial de energia para fins como uso em meios de transporte rápidos e eficientes e em boa parte das atividades industriais. Pontuam os autores que essas fontes não vão durar mais do que algumas décadas: como combustíveis fósseis, as suas reservas são finitas, a segurança de abastecimento é problemática para os muitos países que os importam e o seu uso é a principal fonte dos gases que estão provocando mudanças climáticas e o aquecimento global. 
Alternativas para o suprimento de energia sempre foram buscadas. Entretanto, o que se observa hoje são preocupações que vão além da satisfação das necessidades humanas, e buscam olhar para o futuro do planeta, trazendo para o centro da discussão as fontes renováveis de energia. Para Costa e Prates (2005), energia renovável é uma expressão usada para descrever uma ampla gama de fontes de energia que são disponibilizadas na natureza de forma cíclica, dentre as quais pode-se destacar: a biomassa, a energia eólica, a energia solar, a energia de marés e pequenas centrais hidroelétricas.

Tendo em vista o foco desta pesquisa, destaca-se a biomassa, a qual tem sido a matéria-prima utilizada na produção de biocombustíveis e compreende a matéria vegetal gerada pela fotossíntese e seus diversos produtos e subprodutos derivados, tais como florestas, culturas e resíduos agrícolas, dejetos animais e matéria orgânica, contida nos rejeitos industrial e urbano. Essa matéria contém a energia química acumulada através da transformação energética da radiação solar e pode ser diretamente liberada por meio da combustão, ou ser convertida, através de diferentes processos, em produtos energéticos de natureza distinta, tais como carvão vegetal, etanol, gases combustíveis e de síntese, óleos vegetais combustíveis e outros (EPE, 2008).

Atualmente, há diferentes rotas para transformar a biomassa em biocombustíveis e calor útil. Além dos processos físicos, puramente mecânicos, para concentração, redução granulométrica, compactação ou redução da umidade da biomassa, são utilizados dois grupos de tecnologias químicas, que alteram a composição da matéria-prima para fornecer produtos mais compatíveis com os usos finais: processos termoquímicos, que empregam matériasprimas com baixa umidade e temperaturas elevadas; e processos bioquímicos, desenvolvidos em meios com elevado teor de água e temperaturas próximas à condição ambiente (BNDES, 2008).

A Figura 1 mostra uma síntese das diversas rotas de conversão que podem ser aplicadas. 


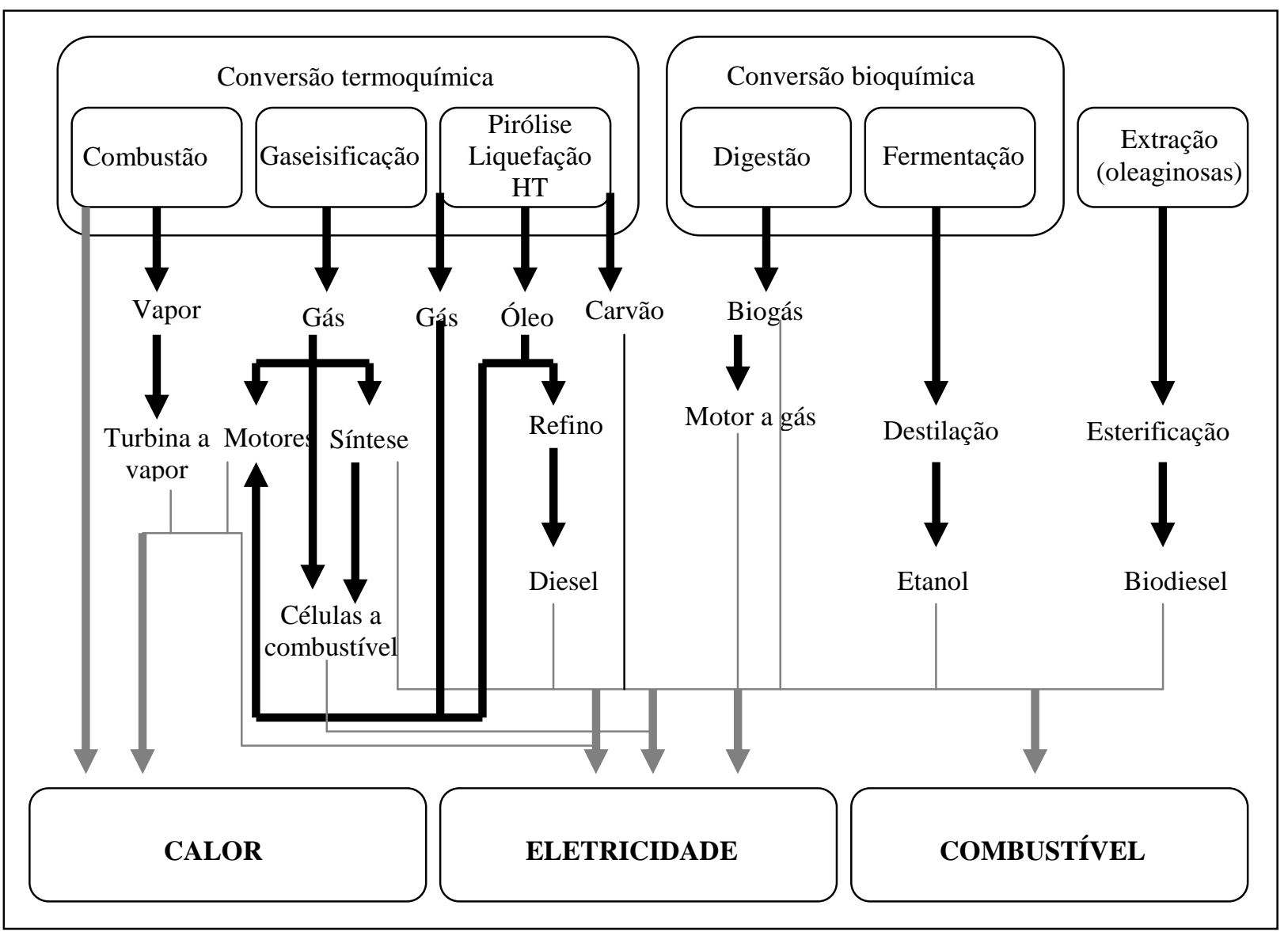

Figura 1 - Rotas tecnológicas para produção de bioenergia

Fonte: BNDES (2008).

Nesta pesquisa, interessa os fatores relacionados ao etanol.

Segundo a Empresa de Planejamento Energético (EPE, 2008), as políticas de incentivo à produção e uso do etanol como combustível, por vários países, têm como principal objetivo a segurança energética, pois diversifica a matriz de insumos energéticos e reduz a dependência dos derivados de petróleo. Além disso, contribui para a redução dos impactos ambientais, sobretudo através da mitigação de emissões de gases de efeito estufa (GEEs), e ainda fortalece a economia rural.

Para a EPE (2008), uma questão fundamental rege o futuro dos biocombustíveis e do etanol em particular: em que quantidade e onde poderiam ser disponibilizados? Para a Empresa, ligada ao Ministério de Minas e Energia do Brasil, não é uma pergunta simples de responder, já que o potencial de oferta dos biocombustíveis não é um número absoluto e estático, como uma reserva mineral, mas uma estimativa dinâmica, que depende de cenários geográficos, 
econômicos e políticos que se alteram, assim como de tecnologias de produção e conversão, muitas delas ainda em desenvolvimento.

A Figura 2 mostra as três rotas tecnológicas predominantes atualmente no que se refere à produção de etanol.

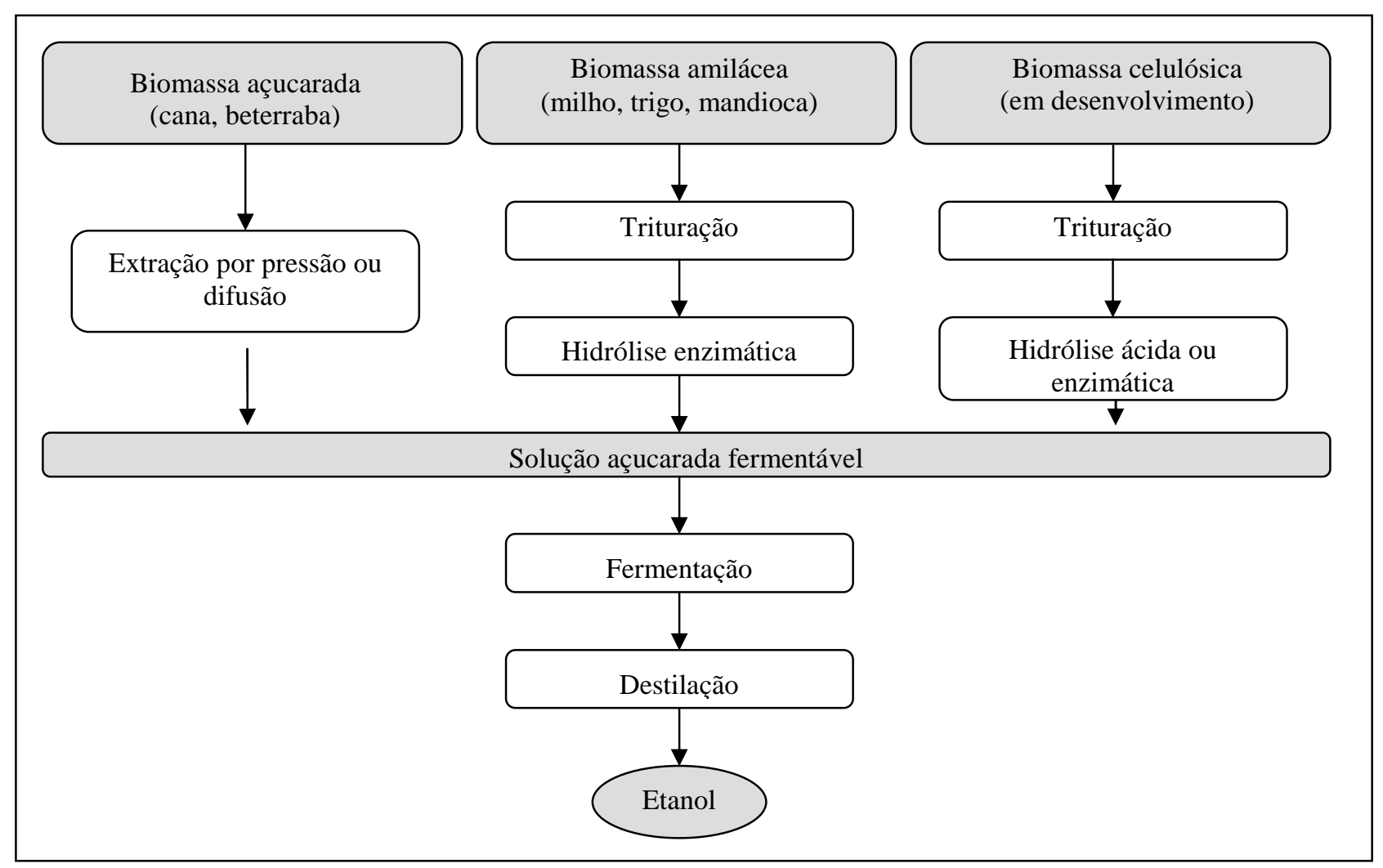

Figura 2 - Rotas tecnológicas para produção de etanol

Fonte: BNDES (2008)

O etanol pode ser produzido com base em qualquer biomassa que contenha quantidades significativas de amido ou açúcares. Atualmente, segundo dados do BNDES (2008), há um leve predomínio da produção com base em materiais amiláceos (53\% do total), como milho, trigo e outros cereais e grãos. Para esses casos, a tecnologia de conversão geralmente começa com a separação, a limpeza e a moagem do grão. A moagem pode ser úmida, quando o grão é embebido e fracionado antes da conversão do amido a açúcar (via úmida), ou seca, quando isso é feito durante o processo de conversão (via seca). Em ambos os casos, o amido é tipicamente convertido em açúcares por meio de um processo enzimático a altas temperaturas (BNDES, 2008). Os açúcares liberados são, então, fermentados por leveduras, e o vinho 
resultante é destilado para a purificação do etanol. Além do etanol, esses processos envolvem, geralmente, diversos co-produtos, que variam conforme a biomassa utilizada.

Associadas às diferentes rotas tecnológicas, devem ser analisados fatores como custo de produção e produtividade, que são importantes direcionadores da competitividade do etanol no mercado internacional. Atualmente, a liderança em produtividade (Gráfico 1) e custo (Gráfico 2) pertence ao etanol produzido a partir de cana-de-açúcar, tecnologia dominada pelo Brasil.

\section{Gráfico 1 - Produtividade média do etanol por área para diferentes culturas}

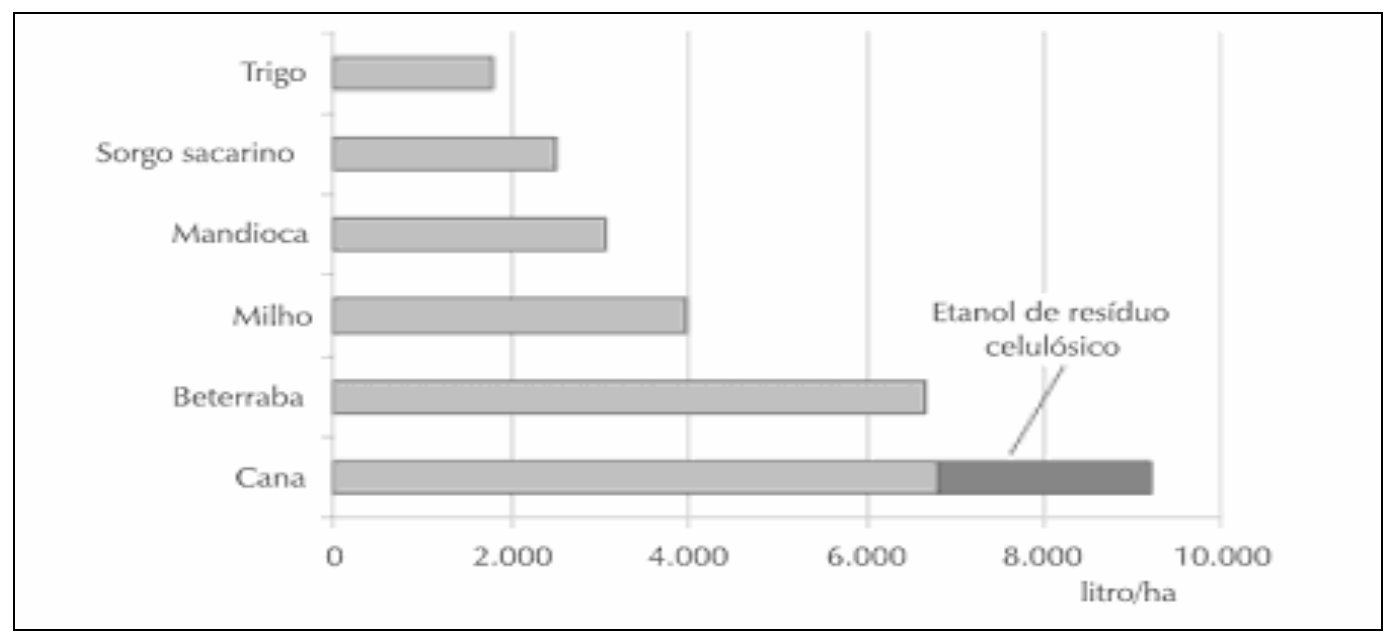

Fonte: BNDES (2008), a partir de dados do GPC (2008)

Gráfico 2 - Custo de produção de etanol (US\$/galão)

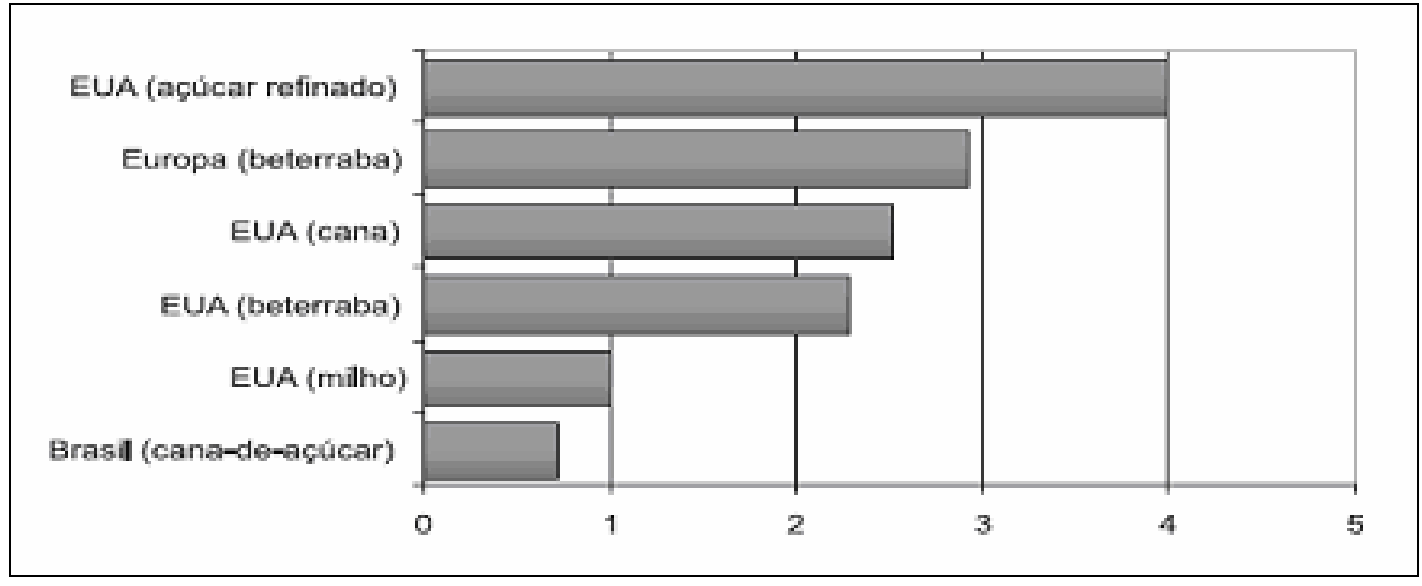

Fonte: Bastos (2007), com dados do USDA 
Segundo Bastos (2007), nos Estados Unidos, os custos variáveis do etanol do milho estão em US\$ 0,96/galão e os custos fixos entre US\$ 1,05 e US\$ 3,00, enquanto o Brasil tem custos variáveis de US\$ 0,89/galão e custos fixos de US\$ 0,21/galão, com custos totais de US\$ $1,10 /$ galão.

De acordo com dados do BNDES (2008), dos 51 bilhões de litros de etanol produzidos em 2006, a produção norte-americana, com base no milho, e a brasileira, com base na cana-deaçúcar, representaram aproximadamente $70 \%$ do total mundial, conforme mostra o Gráfico 3.

\section{Gráfico 3 - Distribuição da produção mundial de etanol em 2006}

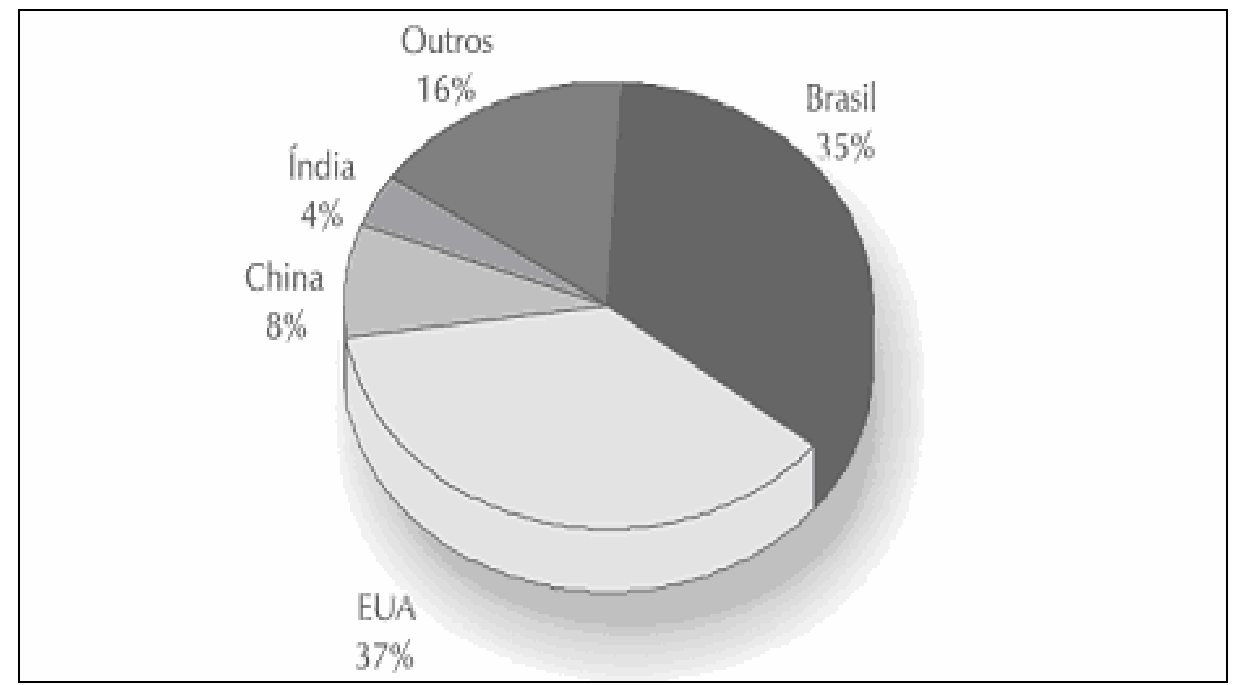

Fonte: BNDES (2008)

A abertura do mercado internacional, com a presença dos EUA, dos países europeus e da China, oferece amplas perspectivas de negócios para todos, especialmente para companhias brasileiras e americanas, que representam mais de $70 \%$ da produção mundial. Grandes tendências podem ser apontadas no mercado (UNICA, 2007a):

- Brasil: a força interna da cana virá basicamente em função da demanda gerada pela frota de veículos flex fuel;

- EUA: produzirão e demandarão volumes crescentes de etanol, estimulados por políticas públicas que visam à modernização da sua matriz energética, à redução das fontes externas de suprimento e à valorização da agricultura; 
- UE: terá demanda aumentada significativamente, ainda mais depois de renovada a meta de usos de energias de fontes renováveis na Europa (dos atuais 7\% para 20\% até 2020);

- Ásia: interesse crescente pelo etanol como combustível na China, Índia, Tailândia e Japão.

Bacchi, Cabrini e Marjotta-Maistro (2007) afirmam que, apesar do mercado doméstico ser o principal destino da produção de etanol do País, a demanda externa tem aumentado significativamente. Segundo os autores, de 2000 a 2006 diversos países adotaram o etanol em sua matriz energética, com destaque para Estados Unidos, Brasil e, na América do Sul, Colômbia, Peru, Venezuela e Paraguai. Os EUA formam o país que mais expandiu a produção de etanol, mas têm uma demanda potencial acima da sua capacidade de abastecimento. Para os países integrantes da iniciativa da Bacia do Caribe (CBI) é permitida uma cota de importação de $7 \%$ sem tarifa de importação. Algumas empresas brasileiras aproveitam essa cota para exportar para os EUA por meio de triangulação com estes países. No entanto, a ação tende a diminuir conforme os países da América Central e Caribe - que já produzem cana para fabricação de açúcar - aumentem sua produção e exportação para os EUA.

Em 2007, Brasil e Estados Unidos assinaram um memorando de entendimento, expressando a intenção de cooperação no desenvolvimento e na difusão dos biocombustíveis numa estratégia de três níveis (AGROANALYSIS, 2007):

I. Bilateral: Os Participantes pretendem avançar na pesquisa e no desenvolvimento de tecnologia para biocombustíveis de nova geração, potencializando, sempre que possível, o trabalho em andamento no âmbito do Mecanismo de Consultas entre o Ministério do Desenvolvimento, Indústria e Comércio do Brasil e o Departamento de Comércio dos Estados Unidos (Diálogo Comercial Brasil-Estados Unidos); do Comitê Consultivo Agrícola (2003); do Mecanismo de Consultas sobre Cooperação na Área de Energia (2003); da Agenda Comum Brasil - Estados Unidos sobre Meio Ambiente (1995); e da Comissão Mista Brasil Estados Unidos de Cooperação Científica e Tecnológica (1984, emendada e ampliada pelo Protocolo assinado em 21 de Março de 1994). 
II. Terceiros Países: Os Participantes tencionam trabalhar conjuntamente para levar os benefícios dos biocombustíveis a terceiros países selecionados por meio de estudos de viabilidade e assistência técnica que visem a estimular o setor privado a investir em biocombustíveis. Os países tencionam começar a trabalhar na América Central e no Caribe encorajando a produção local e o consumo de biocombustíveis, com vistas a trabalhar conjuntamente em regiões-chave do globo.

III. Global: Os Participantes desejam expandir o mercado de biocombustíveis por meio da cooperação para o estabelecimento de padrões uniformes e normas. Para atingir esse objetivo, os Participantes tencionam cooperar no âmbito do Fórum Internacional de Biocombustíveis (FIB), levando em conta o trabalho realizado pelo Instituto Nacional de Metrologia, Normalização e Qualidade do Brasil (INMETRO) e o Instituto Norte-Americano de Padrões e Tecnologia (NIST), bem como coordenando posições em fóruns internacionais complementares.

Nesse entendimento, o governo Bush indicou sete países considerados estratégicos para o programa Brasil-Estados Unidos de cooperação no etanol: Peru, Colômbia, El Salvador, Honduras, Haiti, Guatemala, São Cristóvão e Névis e República Dominicana, que terão acesso à recursos para investimentos conjuntos para a construção de usinas de etanol (AGROANALYSIS, 2007).

Cabe destacar algumas regulamentações recentes que apontam para o aumento da demanda por etanol. Os Estados Unidos adotaram, ao final de 2007, uma ambiciosa legislação estabelecendo a meta de consumo de 136 bilhões de litros de etanol em 2022; Colômbia, Tailândia e dez províncias chinesas instituíram a adição compulsória de $10 \%$ de etanol à gasolina (E-10), enquanto na Índia o percentual de mistura é de 5\% (E-5); e na União Européia encontra-se em discussão uma diretiva propondo a mistura de 10\% de combustíveis renováveis aos fósseis até 2020 (KUTAS; ZECHIN, 2008).

Apesar das crescentes oportunidades, podem ser apontadas ameaças à expansão do consumo de etanol. Segundo Timossil (2008), as crescentes críticas por parte da mídia européia, sociedade civil, determinados governos e demais policy makers e de lobbies agrícolas levantam sérias dúvidas sobre os potenciais ganhos para o etanol no mercado europeu. Afirma o autor que, por ser uma tecnologia genuína do Cone Sul, determinados setores produtivos 
europeus ficaram constrangidos. O lobby agrícola, por exemplo, de início não reconheceu a supremacia do Brasil na área. No Reino Unido, muitos informativos citavam os Estados Unidos, e até mesmo a Austrália, como modelos de produção de energia verde. Essa diferença foi superada à medida que os europeus estabeleceram sua capacidade produtiva. O Quadro 1 mostra a cronologia dos biocombustíveis na União Européia.

\begin{tabular}{|c|c|}
\hline 2003 & - Estabelecimento de diretivas para o uso e a produção de biocombustíveis \\
\hline 2005 & Recomendação para mistura de $2 \%$ de biocombustíveis nos combustíveis fósseis \\
\hline 2007 & $\begin{array}{l}\text { - Conferência Internacional de Biocombustíveis em Bruxelas: "UE importará apenas } \\
\text { biocombustíveis sustentáveis". } \\
\text { - Publicações de entidades da sociedade civil e artigos na imprensa criticam os biocombustíveis } \\
\text { por serem um risco à preservação da biodiversidade, em particular o etanol brasileiro. }\end{array}$ \\
\hline 2008 & $\begin{array}{l}\text { - Comissão Européia apresenta proposta de revisão de Lei sobre Biocombustíveis, com a inclusão } \\
\text { de um percentual de } 10 \% \text { de mistura ao combustível fóssil mandatórios para 2020. A proposta é } \\
\text { vinculada à implementação de critérios de sustentabilidade. } \\
\text { - Sem acordo entre os estados membros, o projeto de lei fica em aberto para novas discussões. } \\
\text { - Instituições internacionais (Banco Mundial, Fundo Monetário Internacional e OCDE) fazem } \\
\text { declarações e alertam para os riscos dos biocombustíveis. Os discursos variam da destruição da } \\
\text { biodiversidade a questões de segurança alimentar. } \\
\text { - Presidente Lula lança força-tarefa para rebater as críticas aos biocombustíveis. }\end{array}$ \\
\hline 2010 & - Recomendação para adição de 5,75\% de biocombustíveis aos combustíveis fósseis. \\
\hline 2020 & $\begin{array}{l}\text { - Aplicação mandatória da mistura de } 10 \% \text { de biocombustíveis aos combustíveis fósseis. Se } \\
\text { aprovada a lei, as importações representarão até } 30 \% \text { do consumo. } \\
\text { - Consolidação dos biocombustíveis de segunda geração. }\end{array}$ \\
\hline
\end{tabular}

\section{Quadro 1 - União Européia: cronologia dos biocombustíveis}

Fonte: Timossil (2008)

Nesse contexto, Rodrigues e Rodrigues (2008) afirmam que a forte demanda por combustíveis renováveis no mercado internacional promove uma reestruturação no setor sucroalcooleiro. Os investimentos no Brasil para o cenário 2007 a 2012, em novos projetos de usinas de açúcar e álcool totalizam US\$ 17 bilhões, com 86 plantas, sendo US\$ 14 bilhões em novas unidades e US\$ 3 bilhões em unidades produtivas existentes. Diante do alto custo para realizar novas aquisições, as empresas podem optar pela realização de investimento greenfield (construção de usinas novas) para não parar de crescer e entrar no setor. O Quadro 2 mostra uma fotografia do setor sucroalcooleiro no Brasil. 


\begin{tabular}{|l|l|l|l|l|l|l|}
\hline & \multicolumn{3}{|c|}{ Safra 2006/07 } & \multicolumn{3}{c|}{ Safra 2012/13 } \\
\hline Parâmetros & Centro-Sul & Norte-Nordeste & Total & Centro-Sul & Norte-Nordeste & Total \\
\hline Unidades produtivas & 231,0 & 74,0 & 325,0 & 337,0 & 75,0 & 412,0 \\
\hline Área colhida (mil ha) & $4.513,7$ & 854,8 & $5.368,5$ & $7.856,2$ & 923,1 & $8.779,3$ \\
\hline Área cultivada (mil ha) & $5.310,2$ & $1.005,7$ & $6.315,9$ & $9.242,6$ & $1.086,0$ & $10.328,6$ \\
\hline Colheita (milhões de t) & 372,4 & 53,0 & 425,4 & 667,8 & 60,0 & 727,8 \\
\hline Produtividade (t/ha) & 82,5 & 62,0 & 79,2 & 85,0 & 65,0 & 82,9 \\
\hline Açúcar (milhões t) & 25,8 & 1,7 & 29,8 & 34,0 & 4,5 & 38,5 \\
\hline Álcool (bilhões de l) & 16,0 & 7,1 & 17,7 & 36,0 & 2,0 & 38,0 \\
\hline Mix de produção (\%) & & & & & & 57,72 \\
\hline Açúcar & 49,51 & 58,8 & 50,58 & 36,48 & 57,0 & 38,12 \\
\hline Álcool & 50,49 & 41,2 & 49,42 & 63,52 & 42,28 & 61,88 \\
\hline Destino da produção (\%) & & & & & & 54,31 \\
\hline Mercado interno & 57,28 & 52,11 & 56,68 & 65,43 & 50,98 & 35,69 \\
\hline Mercado externo & 42,72 & 47,89 & 43,32 & 34,57 & 49,02 & \\
\hline
\end{tabular}

\section{Quadro 2 - Setor sucroalcooleiro no Brasil}

Fonte: UNICA (2007b)

No cenário até 2012/13, a produção de cana-de-açúcar deverá chegar a 727,8 milhões de toneladas, um aumento próximo de 300 milhões de toneladas.

Apesar de perspectivas interessantes, há diversos desafios a serem superados no estabelecimento de um mercado internacional de etanol, como as barreiras tarifárias e o estabelecimento de um padrão internacional para o produto.

Segundo Kutas e Zechin (2008), não obstante o aumento dos volumes exportados pelo Brasil aos Estados Unidos, a tarifação aplicada pelos americanos às importações de etanol brasileiro afeta direta e negativamente a competitividade do produto. A tarifação consiste no pagamento de US\$ 0,54 por galão de etanol importado, mais uma tarifa ad valorem de 2,5\%. Paralelamente a essa taxa, há o benefício fiscal concedido aos blenders, que recentemente foi reduzido de US\$ 0,54 para US\$ 0,45 por galão, segundo a Lei Agrícola (Farm Bill).

Trabalhos conjuntos realizados por técnicos do Brasil, União Européia (UE) e Estados Unidos, identificaram as principais divergências e convergências existentes entre as normas de cada um. Uma das conclusões do estudo é que não há especificações técnicas que 
representem um impedimento à livre circulação do etanol no mercado internacional. Das 15 especificações examinadas, oito são compatíveis nos três mercados, como aparência, densidade e conteúdo de sulfato, enxofre, cobre, aço e sódio; e sete são diferentes, mas podem ser alinhadas no curto prazo, como acidez, conteúdo de fósforo e resíduos de evaporação (SILVA JR., 2008). Silva Jr. (2008) destaca que a única especificação que apresentou dificuldades de compatibilização foi o teor de água de álcool anidro, que atinge 0,24\% (em volume) na União Européia, $1 \%$ nos EUA e 0,56\% no Brasil. Apesar do Brasil aceitar negociar até $0,5 \%$ de teor, há resistências para esse número, principalmente da União Européia.

Há ainda o desafio pela corrida tecnológica para a competitividade e captura de oportunidades. No futuro, mesmo de forma incompleta, novas tecnologias ainda nãocomerciais serão lançadas, com impacto nas áreas de (UNICA, 2007c):

- Genética: variedades resistentes a pragas (broca), maior teor de açúcar, maior produção de biomassa, tolerância à seca, ciclo de produção mais curto e precocidade.

- Mecanização: agricultura de precisão.

- Indústria: automação e separação do etanol.

- Gaseificação: aumento da produção de energia elétrica por meio de ciclos combinados de turbina à gás ou de combustíveis líquidos.

- Hidrólise do bagaço e da palha para a produção de etanol e de outros produtos de fermentações (plásticos, ácidos orgânicos e solventes).

Szwarc (2008) enfatiza que as pesquisas em curso com variedades de cana geneticamente modificadas trazem uma perspectiva de aumento considerável de produtividade e, conseqüentemente, menor demanda por terras e insumos, o que sinaliza um potencial de benefícios ambientais significativos. Segundo o autor, a produção dos chamados biocombustíveis de segunda geração, utilizando o bagaço e a palha da cana, envolvem o desenvolvimento de diversas rotas tecnológicas como a hidrólise, a pirólise, a gaseificação e novos processos de fermentação. Vários países estão investindo na busca pelo domínio dessas tecnologias, que, dentro de um prazo de dez anos, podem tornar viável a produção de biocombustíveis de inúmeras matérias-primas, inclusive de lixo urbano. 
Szwarc (2008) aponta, ainda, que as possibilidades de uso do etanol no setor de transporte de passageiros e de cargas também são reais, com destaque para:

- Motores a diesel otimizados para o uso do etanol já são realidade na Suécia, onde equipam 600 ônibus urbanos, e estão sendo avaliados para uso no Brasil. A versão mais avançada desse motor, lançada recentemente, apresenta níveis de emissão de poluentes que se aproximam de zero e atende, com folga, às severas exigências de controle de poluição da União Européia que entram em vigor em 2009. Atualmente, esses motores estão sendo testados na Suécia em caminhões de lixo, de entregas urbanas e, também, em ônibus híbridos, que operam com etanol e energia elétrica.

- Outra rota tecnológica que vem sendo desenvolvida são os motores que podem operar simultaneamente com óleo diesel e etanol e ser utilizados em veículos rodoviários, tratores, motores estacionários e inúmeras outras aplicações, apresentando emissão de poluentes reduzida.

- O uso do etanol na aviação é uma nova fronteira, que começou a ser desbravada com o Ipanema a álcool. Trata-se de um avião agrícola produzido em escala industrial, cujo motor movido a gasolina de aviação foi adaptado para 100\% de etanol. A escalada dos preços do petróleo, que tem encarecido sobremaneira os combustíveis de aviação, e a necessidade de redução de gases de efeito estufa no setor aeronáutico, são fatores motivadores para a busca de combustíveis alternativos e oportunidades para inovação.

Outro desafio presente no estabelecimento de um mercado internacional de etanol refere-se à sua interação com a produção de alimentos, onde foi levantado o questionamento se a alta recente dos preços dos alimentos foi causado pela destinação de commodities destinadas à alimentação para a produção de biocombustíveis.

Segundo Barros et al. (2008), diante das suspeitas lançadas e dos debates acerca dos biocombustíveis, é fundamental entender como e por que ocorreu a mudança histórica dos preços dos alimentos, quais forças impulsionaram as cotações das commodities agrícolas, bem como qual seria, afinal, a importância dos biocombustíveis nesse processo. Os autores, a partir de um estudo realizado pela Organização das Nações Unidas para Agricultura e Alimentação (FAO), há um conjunto de fatores que explicam a alta recente dos preços dos alimentos: 1. Crescimento da demanda por alimentos e mudança da sua estrutura de consumo - mais proteína e menos carboidratos -, graças ao crescimento de renda da população e à 
urbanização dos países menos desenvolvidos; 2. Utilização de cereais e outros produtos agrícolas na fabricação de biocombustíveis; 3. Operações nos mercados financeiros; 4. Quebras de safra provocadas pelo clima; 5. Baixo nível de estoques de cereais, resultado de mudanças de políticas públicas ou de quebras de safra; 6. Custos crescentes de combustíveis e fertilizantes; 7. Desvalorização do dólar a partir de 2002; 8. Medidas protecionistas adotadas após o início da alta dos preços. Entre elas, a proibição da exportação de alimentos e a desvalorização cambial em relação ao dólar. Essas medidas teriam contribuído para a elevação dos preços dos alimentos nos mercados de outros países. O Quadro 3 apresenta especificidades relacionadas aos fatores identificados.

\begin{tabular}{|c|c|}
\hline Fator & Especificidade \\
\hline Renda e população & $\begin{array}{l}\text { Fenômeno demográfico e crescimento da renda continuarão a pressionar a demanda por } \\
\text { alimento. De acordo com a FAO e o Banco Mundial, as perspectivas são de que, para os } \\
\text { próximos } 30 \text { anos, a renda per capita cresça } 2 \% \text { ao ano em média no mundo e } 4 \% \text { ao ano } \\
\text { nos países em desenvolvimento. }\end{array}$ \\
\hline $\begin{array}{l}\text { Biocombustíveis e } \\
\text { produtos agrícolas }\end{array}$ & $\begin{array}{l}\text { Teria havido, em suma, maior procura por produtos agrícolas para fins de energia. E, } \\
\text { conforme insistem os críticos dos biocombustíveis, ela pode ter aberto uma relativa } \\
\text { competição por área de plantio. Pode, ainda, ter desviado a produção destinada ao } \\
\text { consumo alimentar para as refinarias de combustíveis. É provável que ambas as } \\
\text { condicionantes tenham levado ao aumento de preços dos alimentos. }\end{array}$ \\
\hline $\begin{array}{l}\text { Produção de etanol } \\
\text { de milho }\end{array}$ & $\begin{array}{l}\text { É significativo o volume consumido de milho para a produção de etanol nos Estados } \\
\text { Unidos. Novas tecnologias, com a da utilização de celulose para fabricar etanol e de } \\
\text { subprodutos do refino de biocombustíveis como componentes de rações, aliviaram a } \\
\text { pressão sobre as áreas agrícolas, com diminuição no custo de produção de proteína } \\
\text { animal. No médio prazo, existe a possibilidade de que venham a ser desprezíveis os } \\
\text { efeitos da procura por biocombustíveis sobre os produtos agrícolas. }\end{array}$ \\
\hline $\begin{array}{l}\text { Produção de etanol } \\
\text { de cana }\end{array}$ & $\begin{array}{l}\text { Uma questão a ser atentamente examinada é se a área plantada de cana-de-açúcar tem } \\
\text { crescido no Brasil, em detrimento da ocupada por grãos. A resposta é negativa. Entre } \\
1971 \text { e 2007, basicamente o período de vida do Proálcool, o crescimento da área de grãos } \\
\text { no Brasil foi mais do que quatro vezes superior ao da cultivada com cana-de-açúcar. }\end{array}$ \\
\hline $\begin{array}{l}\text { Operações nos } \\
\text { mercados } \\
\text { financeiros }\end{array}$ & $\begin{array}{l}\text { Trabalho realizado pela Organização para Cooperação e Desenvolvimento Econômico } \\
\text { (OCDE) aborda a possibilidade de que os preços à vista das commodities possam ser não } \\
\text { uma causa, mas sim consequiência de preços futuros inflacionados pela crescente posição } \\
\text { comprada de investidores. } \\
\text { Um indício forte dessa possibilidade está no crescimento, no período } 2006 \text { a } 2008 \text {, do } \\
\text { número de contratos na Bolsa de Chicago (CBOT) em posição comprada por non- } \\
\text { commercial traders (especuladores) no total de contratos long position. }\end{array}$ \\
\hline
\end{tabular}

Quadros 3 - Determinantes do aumento do preço dos alimentos

Fonte: adaptado de Barros et al. (2008) 
Barros et al. (2008) concluem que a expansão da produção de biocombustíveis não é fator relevante para a alta recente dos preços dos alimentos - dos grãos de milho, soja, trigo e arroz. O que contribuiu, decisivamente, para o aumento dos preços em 2007 e 2008, foram, em primeiro plano, a atividade especulativa nos mercados futuros e, como cenário de referência, o aumento da demanda em uma conjuntura de estoques baixos. 


\section{REFERENCIAL TEÓRICO}

\subsection{Capacidades dinâmicas e competitividade}

Segundo Vasconcelos e Cyrino (2000), a Teoria das Capacidades Dinâmicas elabora as idéias colocadas nas teorias dos processos de mercado e na teoria dos recursos (Resource Based View), tendo em vista formular uma teoria da formação das competências organizacionais em ambientes de alta complexidade e mudança. Segundo os autores, essa síntese teórica pretende acentuar os aspectos de co-evolução entre ambientes concorrenciais crescentemente complexos e as capacidades e os recursos das firmas.

Trata-se, nesse caso, de construir um sistema capaz de gerar uma série continuada de inovações a partir da reconfiguração repetida da base de recursos da firma.

Segundo Vasconcelos e Cyrino (2000), na abordagem das capacidades dinâmicas, mais importante que o estoque atual de recursos é a capacidade de acumular e combinar novos recursos em novas configurações capazes de gerar fontes adicionais de rendas.

Para Volberda (2004), a escola das competências dinâmicas considera a gestão estratégica como um processo de aprendizado coletivo, focado no desenvolvimento de capacitações distintas, difíceis de serem copiadas. Essa nova abordagem procura desvendar uma caixapreta ao definir a empresa como um pacote de recursos empresariais que podem levar a performances superiores. Segundo o autor, além da teoria da firma baseada em recursos, teorias empreendedoras e da inovação também contribuem para essa escola.

Em seu estudo Zahra, Sapienza e Davidsson (2006) contribuem na discussão acadêmica sobre capacidades dinâmicas apresentando as definições-chave encontradas na literatura, conforme mostra o Quadro 4. 


\begin{tabular}{|c|c|}
\hline Autor & Definição \\
\hline Helfat (1997) & $\begin{array}{l}\text { Um conjunto de competências/capacidades que permitem que as empresas criem } \\
\text { novos produtos e processos e respondam a circunstâncias mutantes de mercados. }\end{array}$ \\
\hline Teece et al. (1997) & $\begin{array}{l}\text { A habilidade da firma de integrar, construir e reconfigurar competências internas e } \\
\text { externas em face de ambientes rapidamente mutantes. }\end{array}$ \\
\hline $\begin{array}{l}\text { Eisenhardt e Martin } \\
(2000)\end{array}$ & $\begin{array}{l}\text { Os processos da empresa que usam recursos - especificamente os processos para } \\
\text { integrar, reconfigurar, ganhar e disponibilizar recursos - para responder ou até mesmo } \\
\text { criar mudanças no mercado. Portanto, capacidades dinâmicas são rotinas } \\
\text { organizacionais e estratégicas por meio das quais as empresas atingem novas } \\
\text { configurações de recursos na medida em que o mercado emerge, colide, se espalha, } \\
\text { desenvolve e morre. }\end{array}$ \\
\hline $\begin{array}{l}\text { Griffith e Harvey } \\
(2001)\end{array}$ & $\begin{array}{l}\text { Uma capacidade dinâmica global é a criação de combinações de recursos difíceis de } \\
\text { imitar, incluindo a coordenação efetiva de relações interorganizacionais, em uma base } \\
\text { global que pode prover uma vantagem competitiva para a empresa. }\end{array}$ \\
\hline Lee at al. (2002) & $\begin{array}{l}\text { Uma nova fonte de vantagem competitiva na conceituação de como as empresas são } \\
\text { capazes de superar mudanças ambientais. }\end{array}$ \\
\hline $\begin{array}{l}\text { Rindova e Taylor } \\
(2002)\end{array}$ & $\begin{array}{l}\text { Capacidades dinâmicas surgem em dois níveis: uma micro-evolução através da } \\
\text { melhoria de capacidades de gestão da firma e uma macro-evolução associada com a } \\
\text { reconfiguração das competências de mercado. }\end{array}$ \\
\hline Zahra e George (2002) & $\begin{array}{l}\text { Capacidades dinâmicas são essencialmente capacidades orientadas para a mudança que } \\
\text { auxiliam as empresas à redefinir e reconfigurar sua base de recursos para responder } \\
\text { demandas de consumidores e estratégias dos competidores que estão se desenvolvendo }\end{array}$ \\
\hline Zollo e Winter (2002) & $\begin{array}{l}\text { Uma capacidade dinâmica é um padrão estável e aprendido de atividade coletiva } \\
\text { através do qual a organização sistematicamente gera e modifica suas rotinas de } \\
\text { operação para adquirir melhorias de efetividade. }\end{array}$ \\
\hline Winter (2003) & iar capacidades. \\
\hline
\end{tabular}

\section{Quadro 4 - Definições-chave de capacidades dinâmicas}

Fonte: Zahra, Sapienza e Davidsson (2006)

Das definições apresentadas, é relevante destacar as de Eisenhardt e Martin (2000) e Teece, Pisano e Shuen (1997).

Eisenhardt e Martin (2000) desafiam a visão tradicional de capacidades dinâmicas no que se refere à forma como é definida, heterogeneidade, padrão, resultado, vantagem competitiva e evolução, conforme mostra o Quadro 5. 


\begin{tabular}{|c|c|c|}
\hline & $\begin{array}{l}\text { Visão tradicional de capacidades } \\
\text { dinâmicas }\end{array}$ & Reconceitualização de capacidades dinâmicas \\
\hline Definição & Rotinas para aprender rotinas & $\begin{array}{l}\text { Processos organizacionais e estratégicos específicos } \\
\text { (inovação de produto, tomada de decisão estratégica, } \\
\text { alianças) através dos quais administradores alteram } \\
\text { sua base de recursos. }\end{array}$ \\
\hline Heterogeneidade & $\begin{array}{l}\text { Idiossincrática (específica de cada } \\
\text { firma) }\end{array}$ & $\begin{array}{l}\text { Existem pontos em comum (melhores práticas) com } \\
\text { alguns detalhes idiossincráticos }\end{array}$ \\
\hline Padrão & Detalhado, rotinas analíticas & $\begin{array}{l}\text { Depende do dinamismo do mercado, estando entre } \\
\text { rotinas analíticas, detalhadas e rotinas simples, } \\
\text { experimentais }\end{array}$ \\
\hline Resultado & Previsível & $\begin{array}{l}\text { Depende do dinamismo do mercado, previsível ou } \\
\text { imprevisível }\end{array}$ \\
\hline $\begin{array}{l}\text { Vantagem } \\
\text { competitiva }\end{array}$ & $\begin{array}{l}\text { Vantagem competitiva sustentável } \\
\text { advinda de capacidades dinâmicas } \\
\text { valiosas, raras, inimitáveis e } \\
\text { insubstituíveis }\end{array}$ & $\begin{array}{l}\text { Vantagem competitiva advinda de capacidades } \\
\text { dinâmicas valiosas, em algum grau raras, equifinais, } \\
\text { substituíveis e intercambiáveis }\end{array}$ \\
\hline Evolução & Trajetória única & $\begin{array}{l}\text { Trajetória única moldada por mecanismos de } \\
\text { aprendizagem tais como prática, codificação, erros e } \\
\text { cadenciamento }\end{array}$ \\
\hline
\end{tabular}

\section{Quadro 5 - Capacidades dinâmicas e dinamismo do mercado}

Fonte: Eisenhardt e Martin (2000)

A contribuição de Eisenhardt e Martin (2000) está em adicionar o elemento dinamismo do mercado como orientador do conceito mais adequado. Segundo os autores, em mercado moderadamente dinâmicos, capacidades dinâmicas recaem no conceito tradicional de rotinas; elas são detalhadas, analíticas e processos estáveis com resultados previsíveis. Já em mercados com alto dinamismo, elas são simples, altamente experimentais e processos frágeis com resultados imprevisíveis. O Quadro 6 apresenta peculiaridades das capacidades dinâmicas em mercados moderadamente e altamente dinâmicos. 


\begin{tabular}{|c|c|c|}
\hline & Mercados moderadamente dinâmicos & Mercados altamente dinâmicos \\
\hline $\begin{array}{l}\text { Definição do } \\
\text { mercado }\end{array}$ & $\begin{array}{l}\text { Estrutura da indústria estável, fronteiras } \\
\text { definidas, modelos de negócios claros, } \\
\text { players identificáveis, mudanças lineares e } \\
\text { previsíveis }\end{array}$ & $\begin{array}{l}\text { Estrutura da indústria ambígua, fronteiras } \\
\text { pouco definidas, modelos de negócios fluídos, } \\
\text { players ambíguos, mudança não-linear e } \\
\text { imprevisível }\end{array}$ \\
\hline Padrão & $\begin{array}{l}\text { Detalhado, rotinas analíticas que se apóiam } \\
\text { extensivamente em conhecimento existente }\end{array}$ & $\begin{array}{l}\text { Simples, rotinas experimentais que se apóiam } \\
\text { em conhecimentos novos e específicos } \\
\text { conforme a situação }\end{array}$ \\
\hline Execução & Linear & Iterativa \\
\hline Estabilidade & Sim & Não \\
\hline Resultados & Previsíveis & Imprevisível \\
\hline $\begin{array}{l}\text { Chave para } \\
\text { evolução } \\
\text { efetiva }\end{array}$ & Freqüente, variações pequenas & Seleção cuidadosamente gerenciada \\
\hline
\end{tabular}

Quadro 6 - Capacidades dinâmicas e tipos de dinâmica dos mercados

Fonte: Eisenhardt e Martin (2000)

Segundo Teece, Pisano e Shuen (1997), capacidades dinâmicas são habilidades de atingir novas formas de vantagem competitiva. O termo "dinâmicas" refere-se à capacidade de renovar competências tendo em vista alcançar congruência com as mudanças no ambiente de negócios; determinadas respostas inovativas são requeridas quando time-to-market e timing são críticos, a taxa de mudança tecnológica é rápida, e a natureza da competição e mercados futuros são difíceis de determinar. O termo "capacidades" enfatiza o papel central da administração estratégica em adaptar, integrar e reconfigurar habilidades organizacionais internas e externas apropriadamente, bem como recursos e competências funcionais que vão de encontro às exigências do ambiente em mudança. Para os autores há três categorias de fatores que ajudam a identificar as capacidades dinâmicas de uma empresa: processos, posições e trajetórias. Processos gerenciais e organizacionais referem-se ao modo como as atividades são desenvolvidas na empresa, suas rotinas ou padrões de práticas correntes e aprendizagem; posição refere-se aos seus ativos específicos de tecnologia, propriedade intelectual, ativos complementares, base de clientes, e suas relações externas com fornecedores; trajetória são as alternativas estratégicas disponíveis para a empresa, ou a presença ou ausência de retornos crescentes e dependências da trajetória (TEECE; PISANO; SHUEN, 1997). As particularidades de cada categoria são apresentadas no Quadro 7. 


\begin{tabular}{|c|c|c|}
\hline Categoria & Fatores & Conceito \\
\hline \multirow[t]{3}{*}{$\begin{array}{l}\text { Processos } \\
\text { gerenciais e } \\
\text { organizacionais }\end{array}$} & Coordenação/integração & $\begin{array}{l}\text { Coordenação ou integração de atividades internas (produção, } \\
\text { desenvolvimento de produtos e processos, coleta e processamento } \\
\text { de informações) e externas (desenvolvimento colaborativo de } \\
\text { tecnologia, alianças estratégicas, corporações virtuais, relações de } \\
\text { coordenação da cadeia de suprimentos) à empresa. }\end{array}$ \\
\hline & Aprendizagem & $\begin{array}{l}\text { Processo pelo qual a repetição e a experimentação permitem que } \\
\text { tarefas sejam realizadas de forma mais eficiente e melhor, } \\
\text { permitindo também que novas oportunidades de produção sejam } \\
\text { identificadas. Isso envolve habilidades individuais dos } \\
\text { funcionários bem como interações sociais para entender problemas } \\
\text { complexos; requer códigos comuns de comunicação e } \\
\text { procedimentos de busca coordenados. }\end{array}$ \\
\hline & Reconfiguração & $\begin{array}{l}\text { Habilidade de perceber a necessidade de reconfigurar a estrutura } \\
\text { de ativos da empresa, e atingir transformações internas e externas } \\
\text { que sejam necessárias. Isso requer vigilância de mercados e } \\
\text { tecnologias e vontade para adotar as melhores práticas, ou seja, } \\
\text { realizar Benchmarking. }\end{array}$ \\
\hline \multirow[t]{8}{*}{ Posição } & Ativos tecnológicos & As tecnologias da empresa bem como a proteção de propriedade. \\
\hline & Ativos complementares & $\begin{array}{l}\text { Ativos relacionados com a produção e entrega de novos produtos e } \\
\text { serviços, com a força de vendas. }\end{array}$ \\
\hline & Ativos financeiros & Posição de caixa e grau de alavancagem. \\
\hline & Ativos de reputação & $\begin{array}{l}\text { A reputação sumariza um bom acordo de informação sobre a } \\
\text { empresa e dão moldes às respostas de clientes, fornecedores e } \\
\text { competidores. }\end{array}$ \\
\hline & Ativos de estrutura & $\begin{array}{l}\text { Refere-se à estrutura formal e informal da empresa e suas ligações } \\
\text { externas, grau de hierarquia e nível de integração vertical e lateral, } \\
\text { modos de governança (multiprodutos, corporações virtuais, } \\
\text { conglomerados, empresas com alta flexibilidade). }\end{array}$ \\
\hline & Ativos institucionais & $\begin{array}{l}\text { Elementos do ambiente que influenciam o desempenho da empresa } \\
\text { (sistemas regulatórios, regimes de propriedade intelectual, leis } \\
\text { anti-trust, sistema de educação superior e cultura nacional). }\end{array}$ \\
\hline & $\begin{array}{l}\text { Ativos de estrutura de } \\
\text { mercado }\end{array}$ & $\begin{array}{l}\text { Definição do mercado no qual a empresa compete e que oferece } \\
\text { retorno econômico. }\end{array}$ \\
\hline & $\begin{array}{l}\text { Fronteiras } \\
\text { organizacionais }\end{array}$ & Grau de integração (vertical, lateral e horizontal). \\
\hline \multirow[t]{3}{*}{ Trajetória } & $\begin{array}{l}\text { Dependências } \\
\text { trajetória }\end{array}$ & $\begin{array}{l}\text { Refere-se ao histórico da empresa, seus investimentos anteriores e } \\
\text { repertório de rotinas que restringem o seu comportamento futuro. }\end{array}$ \\
\hline & $\begin{array}{l}\text { Oportunidades } \\
\text { tecnológicas }\end{array}$ & $\begin{array}{l}\text { Taxa e direção na qual fronteiras científicas relevantes estão sendo } \\
\text { se movendo. }\end{array}$ \\
\hline & Avaliação & $\begin{array}{l}\text { Envolve replicabilidade e imitação dos determinantes de } \\
\text { desempenho. }\end{array}$ \\
\hline
\end{tabular}

Quadro 7 - Particularidades das categorias de fatores que identificam as

\section{capacidades dinâmicas de uma firma}

Fonte: adaptado de Teece, Pisano e Shuen (1997)

Teece, Pisano e Shuen (1997) sintetizam que a essência da competência e das capacidades dinâmicas de uma empresa reside em seus processos organizacionais, que são moldados por seus ativos (posição de ativos) e sua trajetória evolucionária.

Em trabalho posterior, Teece (2007) desagrega, para efeitos de análise, o conceito de capacidades dinâmicas em (1) capacidade de perceber e moldar oportunidades e ameaças, (2) 
capacidade de capturar oportunidades, e (3) capacidade de manter a competitividade através do desenvolvimento, combinação, proteção, e quando necessário, reconfiguração dos ativos tangíveis e intangíveis da empresa. Teece (2007) apresenta ainda os elementos (microfundamentos) das capacidades dinâmicas, conforme mostra o Quadro 8.

\begin{tabular}{|c|c|c|}
\hline Capacidade & Natureza da capacidade & Elementos \\
\hline $\begin{array}{ll}\text { Perceber } & \mathrm{e} \\
\text { moldar } & \\
\text { oportunidades } & \mathrm{e} \\
\text { ameaças } & \end{array}$ & $\begin{array}{l}\text { Atividades para escanear, criar, aprender } \\
\text { e interpretar novas oportunidades. } \\
\text { Investimento em pesquisa e atividades } \\
\text { relacionadas usualmente são necessários } \\
\text { para complementar as atividades } \\
\text { anteriormente mencionadas. }\end{array}$ & $\begin{array}{l}\text { Processos para dirigir Pesquisa e } \\
\text { Desenvolvimento (P\&D) interno e selecionar } \\
\text { novas tecnologias; Processos para selecionar } \\
\text { inovação de fornecedores e complementadores; } \\
\text { Processos para selecionar desenvolvimento } \\
\text { exógeno em Ciência e Tecnologia; Processos } \\
\text { para identificar segmentos de mercados-alvo, } \\
\text { necessidades de consumidores em mutação e } \\
\text { inovação de consumidores. }\end{array}$ \\
\hline $\begin{array}{l}\text { Capturar } \\
\text { oportunidades }\end{array}$ & $\begin{array}{l}\text { Direcionamento das oportunidades para o } \\
\text { desenvolvimento de novos produtos, } \\
\text { processos ou serviços; habilidades para } \\
\text { tomada de decisões estratégicas. }\end{array}$ & $\begin{array}{l}\text { Delineamento das soluções para clientes e } \\
\text { modelos de negócios: seleção da arquitetura de } \\
\text { tecnologia e produto, design da arquitetura de } \\
\text { receitas, seleção dos clientes-alvo, design dos } \\
\text { mecanismos para capturar valor; Seleção dos } \\
\text { protocolos de tomada de decisão: } \\
\text { reconhecimento de pontos de inflexão e } \\
\text { complementaridades, evitar erros de decisão e } \\
\text { propensão para canibalização; Seleção dos } \\
\text { limites da empresa para gerenciar } \\
\text { complementos e controlar plataformas: } \\
\text { calibração da especificidade do ativo, controle } \\
\text { dos gargalos dos ativos, avaliação da } \\
\text { "apropriabilidade", a reconhecimento, } \\
\text { gerenciamento e captura de economias de co- } \\
\text { especialização; Construção de lealdade e } \\
\text { comprometimento: demonstração de liderança, } \\
\text { comunicação efetiva, reconhecimento de fatores } \\
\text { não-econômicos, valores e cultura. }\end{array}$ \\
\hline $\begin{array}{l}\text { Combinação, } \\
\text { reconfiguração e } \\
\text { proteção de } \\
\text { ativos }\end{array}$ & $\begin{array}{l}\text { A chave para um crescimento sustentável } \\
\text { da lucratividade é a habilidade de } \\
\text { combinar e reconfigurar ativos e } \\
\text { estruturas organizacionais na medida em } \\
\text { que a empresa cresce, e os mercados e as } \\
\text { tecnologias mudam. A reconfiguração é } \\
\text { necessária para manter a adequação } \\
\text { evolucionária, e se necessário, escapar de } \\
\text { dependências de trajetórias } \\
\text { desfavoráveis. }\end{array}$ & $\begin{array}{l}\text { Descentralização: adoção de estruturas } \\
\text { flexíveis, adoção da inovação aberta, } \\
\text { desenvolvimento de habilidades de integração e } \\
\text { coordenação; Governança: atingir alinhamento } \\
\text { de incentivos, minimizar questões de agência, } \\
\text { checar má-conduta estratégica, bloquear a } \\
\text { dissipação de rendas; Co-especialização: } \\
\text { gerenciamento da adequação estratégica de } \\
\text { modo que a combinação de ativos são } \\
\text { impulsionadores de valor; Gestão do } \\
\text { conhecimento: aprendizagem, transferência de } \\
\text { conhecimento, integração de know-how, } \\
\text { proteção de know-how e propriedade } \\
\text { intelectual. }\end{array}$ \\
\hline
\end{tabular}

Quadro 8 - Microfundamentos das capacidades dinâmicas

Fonte: Teece (2007) 
Segundo Teece (2007), a extensão na qual a empresa desenvolve e emprega capacidades dinâmicas superiores determinarão a natureza e o montante de ativos intangíveis que irão criar e o nível de lucro econômico que irão ganhar.

\subsection{Estudos prospectivos e cenários}

No campo dos estudos do futuro, podem ser identificadas duas áreas de pesquisas que apresentam pressupostos e técnicas distintas, sendo elas a previsão (forecasting) e a prospecção (foresight). Jouvenel (2000) afirma que o processo prospectivo apresenta traços essenciais que os distanciam da previsão em geral. Em primeiro lugar, a prospecção usa um enfoque pluridisciplinar de inspiração sistêmica baseada no princípio de que os problemas não podem ser corretamente compreendidos se reduzidos a uma dimensão, como ocorre geralmente quando são abordados a partir de disciplinas acadêmicas distintas. Ao invés disso, a prospecção oferece uma abordagem que captura as realidades em sua totalidade com todas as variáveis que agem sobre elas, baseada no estudo de todos os fatores e suas inter-relações.

Para o Departamento de Prospecção e Planejamento de Portugal (1997), pode-se ir mais longe no confronto entre as abordagens da previsão e da prospecção, conforme mostra o Quadro 9.

\begin{tabular}{|c|c|}
\hline PREVISÃO & PROSPECÇÃO \\
\hline Concentra-se nas Certezas; Oculta as Incertezas & $\begin{array}{c}\text { Concentra-se nas Incertezas, legitimando o seu } \\
\text { reconhecimento }\end{array}$ \\
\hline Origina projeções sobre um único ponto e lineares & $\begin{array}{c}\text { Origina imagens diversas, mas lógicas, do } \\
\text { futuro }\end{array}$ \\
\hline Privilegia as Continuidades & Toma em consideração as Rupturas \\
\hline Afirma o primado do Quantitativo sobre o Qualitativo & Alia Qualitativo e Quantitativo \\
\hline Oculta os Riscos & Sublinha os Riscos \\
\hline Favorece a Inércia & $\begin{array}{c}\text { Favorece uma atitude de Flexibilidade e o } \\
\text { espírito de Responsabilidade }\end{array}$ \\
\hline Parte do que é Simples para o que é Complexo & Parte do que é Complexo, para o que é Simples \\
\hline Adota uma abordagem normalmente setorial & Adota uma abordagem global \\
\hline
\end{tabular}

\section{Quadro 9 - Diferenças entre Previsão e Prospecção}

Fonte: Departamento de Prospecção e Planejamento de Portugal (1997)

A previsão, conforme mostra a coluna esquerda do Quadro 9, é amplamente apoiada por métodos estatísticos e modelagem econométrica, partindo do pressuposto que o passado é um bom preditor do futuro, podendo-se, portanto, privilegiar continuidades e certezas. Por outro 
lado, a prospecção, coluna direita do Quadro 1, considera que o futuro pode ser marcado por incertezas e descontinuidades, devendo-se considerá-las em uma abordagem flexível e qualitativa.

Tendo em vista os aspectos específicos que caracterizam a prospecção, uma técnica adequada para a realização de estudos dessa natureza diz respeito à Técnica de Cenários. Na literatura, podem ser encontradas diversas definições para o termo cenário, a partir de seu uso como ferramenta de prospecção do futuro.

Wright e Spers (2006) afirmam que elaborar cenários não é um exercício de predição, mas sim um esforço de fazer descrições plausíveis e consistentes de situações futuras possíveis, apresentando os condicionantes do caminho entre a situação atual e cada cenário futuro, destacando os fatores relevantes às decisões que precisam ser tomadas.

Schnaars e Topol (1987) afirmam que termo cenário é a combinação de três características básicas: narrativas fluídas, múltiplas projeções e progressão de eventos. Segundo estes autores, cenários são mais estruturados por narrativas fluídas do que por estimativas quantitativas precisas, ou seja, busca mais comunicar a direção geral da mudança do que predizer o futuro com precisão numérica. Essa característica oferece aos usuários insight sobre o progresso e o mecanismo da mudança.

Fahey e Randall (1998) complementam afirmando que cenários são narrativas de projeções alternativas plausíveis de uma parte específica do futuro, oferecendo descrições contrastantes de como vários aspectos incertos do futuro podem se desenvolver.

Pontua Huss (1988) que o resultado mais importante da ferramenta não é predizer exatamente a seqüência de eventos, antes disso, deve oferecer entendimento sobre a dinâmica do ambiente, as tendências-chave para monitorar e os limites dos desfechos do futuro para o qual se pretende planejar. Esses insights auxiliam os tomadores de decisão se não prever pontos de inflexão, pelo menos acessar quando as condições são corretas para uma mudança estrutural de maior porte.

Para que os cenários sejam elaborados, é necessário, portanto, que o cenarista considere um conjunto de forças que atuam sobre o sistema em estudo. Entretanto, a consideração de tais 
forças não deve se limitar à extrapolação de tendências passadas. É preciso ir além e adotar uma abordagem pluralista do futuro, balizada por forças restritivas e forças propulsoras que atuam sobre as variáveis do sistema, bem como os limites naturais ou sociais dentro dos quais as variáveis podem evoluir no horizonte de tempo em análise. A Figura 1 apresenta esquematicamente esta visão, com base nas definições de Wright e Spers (2006), Schnaars e Topol (1987), Fahey e Randall (1998) e Huss (1988).

Forças sociais, econômicas, tecnológicas, políticas; não basta extrapolar índices.

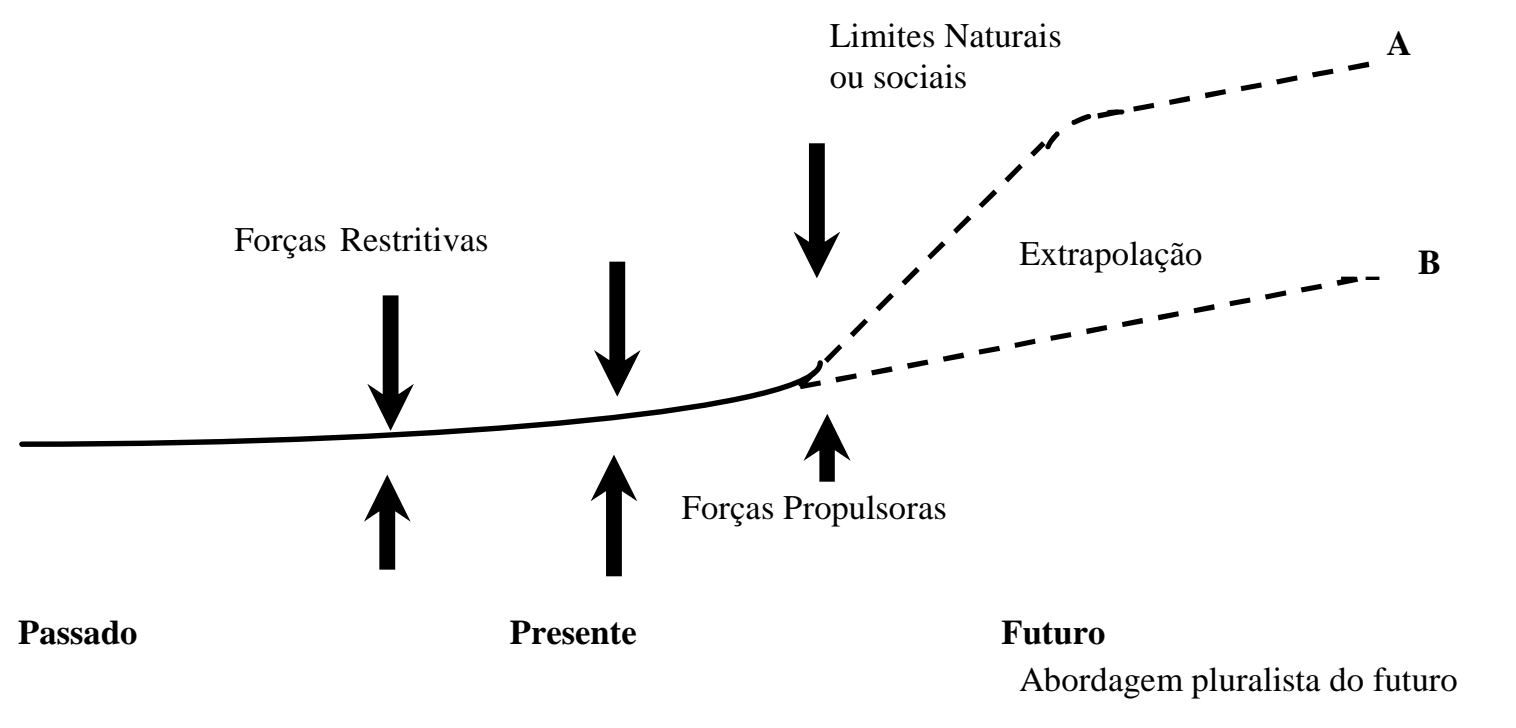

Figura 3 - Visão Esquemática do Conceito de Cenários

Fonte: Wright e Spers (2006)

Há consenso que o mundo hoje é caracterizado por um estado de constantes transformações e muitas destas são de natureza não-linear. Nesse sentido, Huss (1988) afirma que cenários são mais adequados quando aplicados ao longo prazo e à análise macro de ambientes incertos os quais podem ser tipificados por escassez de dados e um grande número de fatores não quantificáveis. Continua o autor, "cenários não identificam perturbações de curto prazo no sistema; a abordagem enfatiza relações e tendências de longo prazo (10-20 anos)".

Assim como Huss (1988), Schoemaker (1995) afirma que organizações podem se beneficiar com o planejamento de cenários quando a incerteza é alta relativamente à habilidade dos gerentes predizer ou ajustar às mudanças do ambiente. 
Schoemaker (1995) afirma que a utilização de cenários beneficia as organizações especialmente em situações que envolvem as seguintes condições:

- Há alto grau de incerteza com relação à capacidade de predizer o futuro ou corrigir rumos;

- Viveu-se um histórico marcado por surpresas desagradáveis e onerosas;

- O pensamento estratégico tem sido de baixa qualidade;

- Mudanças significativas no contexto ocorreram ou estão prestes a ocorrer;

- Há necessidade de uma nova perspectiva e linguagem comuns, sem perder de vista a diversidade;

- Coexistem fortes diferenças de opinião, e muitas delas têm mérito.

Tendo em vista, que, em sua essência, cenários são descrições plausíveis do futuro de determinado sistema, é fundamental identificar a natureza das descrições que podem ser feitas.

Para Coates (2000), cenários utilizados em empresas e em outras organizações podem ser classificados em duas categorias amplas. Uma categoria refere-se a cenários que descrevem algum estado ou condição futura na qual a organização está inserida. Esse cenário é usado para estimular os usuários a desenvolver e clarificar escolhas práticas, políticas, e ações alternativas que podem ser tomadas para responder às consequiências do cenário. A outra categoria descreve uma história diferente. Assume que a política e decisões já foram estabelecidas. As políticas e suas conseqüências são integradas em uma história sobre algum estado futuro. Nesse tipo de cenário, ao invés de estimular a discussão sobre a escolha de políticas, mostra as consequiências de uma escolha particular ou um conjunto de escolhas. $\mathrm{Ou}$ seja, a primeira categoria é usada para estimular o pensamento e a segunda é uma ferramenta para explicar ou explorar as conseqüências de alguma decisão.

Segundo Masini e Vasquez (2000), as diferentes escolas de pensamento sobre a elaboração de cenários adotam um conjunto de tipos, conforme mostra o Quadro 10, sendo que, em linhas gerais os cenários podem ser tendenciais ou extrapolativos, normativos ou desejáveis, catastróficos, utópicos e contrastantes. 


\begin{tabular}{|c|c|}
\hline Escolas & Tipos e definições \\
\hline \multirow{3}{*}{$\begin{array}{l}\text { Cenários Extrapolativos e } \\
\text { Normativos: Erich } \\
\text { Jantsch }\end{array}$} & $\begin{array}{l}\text { Cenários extrapolativos usam dados referentes ao passado e ao presente tendo } \\
\text { em vista o que é possível e provável. }\end{array}$ \\
\hline & $\begin{array}{l}\text { Cenários normativos são projetados do futuro para o presente, retornando ao } \\
\text { futuro novamente. }\end{array}$ \\
\hline & $\begin{array}{l}\text { Cenários extrapolativos podem ser também normativos quando, além de } \\
\text { contemplar o que é possível e provável, contempla o que é desejável. }\end{array}$ \\
\hline \multirow[b]{2}{*}{$\begin{array}{l}\text { Cenários Prováveis e } \\
\text { Desejáveis: Escola } \\
\text { Francesa }\end{array}$} & $\begin{array}{l}\text { Cenários prováveis correspondem ao que acontecerá no futuro, a partir do } \\
\text { conhecimento das atividades dos atores. }\end{array}$ \\
\hline & $\begin{array}{l}\text { Cenários desejáveis indicam o horizonte para o qual nós devemos direcionar } \\
\text { nossos esforços se queremos que as coisas se modifiquem significativamente e } \\
\text { se nós pretendemos ir além dos prognósticos do cenário provável, provendo uma } \\
\text { solução para os problemas que emergem do sistema. }\end{array}$ \\
\hline \multirow{2}{*}{$\begin{array}{l}\text { Cenários de Primeira e } \\
\text { Segunda geração: Escola } \\
\text { Shell-SRI }\end{array}$} & $\begin{array}{l}\text { Cenários de primeira geração são usualmente exploratórios e possuem as } \\
\text { seguintes características: ajudam a obter um melhor entendimento da realidade e } \\
\text { são capazes de levantar melhores questões; não oferecem auxílio maior para a } \\
\text { tomada de decisão; é orientado para o entendimento e não para a ação. }\end{array}$ \\
\hline & $\begin{array}{l}\text { Cenários de segunda geração são baseados em uma análise sólida da realidade; } \\
\text { eles modificam as premissas e suposições daqueles que tomam decisões em } \\
\text { como o mundo funciona e os obriga a reorganizar seu modelo mental de } \\
\text { realidade; são também ferramentas educacionais, pois trabalham nos } \\
\text { mecanismos ou no mundo interno dos tomadores de decisões. }\end{array}$ \\
\hline \multirow{5}{*}{$\begin{array}{l}\text { Cenários Tendenciais, } \\
\text { Otimistas, Pessimistas e } \\
\text { Contrastantes: H. Kahn e } \\
\text { Estudos dos Futuros } \\
\text { Humano e Social }\end{array}$} & $\begin{array}{l}\text { Tendencial-inercial ou Cenários de Tendência: descrevem o prolongamento da } \\
\text { situação presente - o que é presente agora. Não pressupõe mudanças, como se } \\
\text { tudo fosse continuar constante, exatamente igual. }\end{array}$ \\
\hline & $\begin{array}{l}\text { Cenários utópicos: descrevem o melhor dos mundos possíveis, qual seria a } \\
\text { situação ideal. Apesar de usualmente inatingível, o cenário utópico é o mais } \\
\text { desejável, e tem uma proposta altamente didática quando mostra o que não é } \\
\text { atingível. }\end{array}$ \\
\hline & $\begin{array}{l}\text { Cenários catastróficos: descrevem o pior dos mundos possíveis, piorando o que } \\
\text { foi identificado como cenário tendencial. }\end{array}$ \\
\hline & $\begin{array}{c}\text { Cenários normativos: descrevem uma situação desejável e atingível que melhora } \\
\text { o cenário tendencial, estruturando os objetivos para o futuro. São úteis para } \\
\text { definir um certo número de metas atingíveis e razoáveis, e para definir os } \\
\text { estágios necessários para atingir as metas. }\end{array}$ \\
\hline & $\begin{array}{l}\text { Cenários contrastantes: descrevem diferentes situações a partir de variações em } \\
\text { determinadas variáveis-chave. Geralmente são o oposto do cenário tendencial, e } \\
\text { apresenta situações extremas. São aqueles que construídos se todas as surpresas, } \\
\text { presumidas como improváveis no momento de sua enunciação, acontecessem. } \\
\text { Entretanto, eles não são totalmente arbitrários, e focam na descoberta por meio } \\
\text { de análise racional de relações entre fatos que podem não estar suficientemente } \\
\text { visíveis. }\end{array}$ \\
\hline
\end{tabular}

\section{Quadro 10 - Tipos de Cenários}

Fonte: Masini e Vasquez (2000)

Godet (2000) afirma que, na prática, não há um único método para o desenvolvimento de cenários, mas uma variedade de métodos para a construção, sendo alguns simplistas e outros sofisticados. Entretanto, pontua o autor, há um consenso que o termo método de cenários somente se aplica para uma abordagem que inclua um número de etapas específicas inter- 
relacionadas - análise de sistemas, retrospectiva, estratégia dos atores e elaboração de cenários.

Para propostas sérias, Coates (2000) afirma que é necessária uma abordagem sistemática para elaborar cenários. O cenário ideal para o autor é transparente no sentido que o usuário sabe quais as regras usadas para sua construção, entende as etapas do processo e vê o resultado com a percepção que poderia obter o mesmo resultado aplicando o mesmo processo.

Coates (2000) sugere que cenários devem ser elaborados a partir da identificação e definição do universo de preocupação, definição das variáveis que serão importantes para moldar o futuro, identificação dos temas para os cenários e, finalmente, a criação dos cenários.

Em linha semelhante, Jouvenel (2000) propõe que, basicamente, há cinco estágios para o procedimento prospectivo: definição do problema e escolha do horizonte de tempo, identificação das variáveis e construção do sistema, coleta de dados e elaboração de hipóteses, exploração de futuros possíveis e de escolhas estratégicas.

Boaventura, Costa e Fischmann (2005) realizaram um trabalho para identificar os modelos de construção de cenários mais citados, chegando a oito métodos: SRI International; Global Business Network; Future Mapping; Battelle Memorial Institute; Análise Prospectiva; Comprehensive Situation Mapping; Análise do Impacto de Tendências e Decision Strategies International, conforme mostra o Quadro 11.

\begin{tabular}{|c|c|c|}
\hline Métodos & Etapas & Características \\
\hline $\begin{array}{l}\text { SRI International } \\
\text { (Stanford } \\
\text { Research } \\
\text { Institute) }\end{array}$ & $\begin{array}{l}\text { 1. Definição das decisões estratégicas que os cenários deverão } \\
\text { abordar; } 2 \text {. Identificação dos fatores-chave de decisão; } 3 \text {. Análise das } \\
\text { forças ambientais; 4. Desenvolvimento dos cenários lógicos; } 5 . \\
\text { Descrição dos cenários; 6. Identificação das implicações estratégicas } \\
\text { para a tomada de decisão. }\end{array}$ & $\begin{array}{l}\text {-Lógica Intuitiva; } \\
\text { - Interatividade; } \\
\text { - Workshops. }\end{array}$ \\
\hline $\begin{array}{l}\text { Global Business } \\
\text { Network }\end{array}$ & $\begin{array}{l}\text { 1. Identificar a questão ou decisão central; 2. Identificação dos } \\
\text { fatores-chave do ambiente local; } 3 \text {. Identificação das forças motrizes } \\
\text { do macroambiente; 4. Hierarquização dos fatores-chave por } \\
\text { importância e incerteza; 5. Seleção da lógica dos cenários; 6. } \\
\text { Redação dos cenários; 7. Análise das implicações; } 8 \text {. Seleção dos } \\
\text { indicadores iniciais e dos sinais de aviso para monitoramento do } \\
\text { futuro. }\end{array}$ & $\begin{array}{l}\text { - } \text { Aproximação } \\
\text { com o modelo SRI } \\
\text { (Peter Schwartz, } \\
\text { fundador da GBN } \\
\text { era consultor da } \\
\text { SRI International); } \\
\text { - Lógica Intuitiva. }\end{array}$ \\
\hline Future Mapping & $\begin{array}{l}\text { Usa dois conjuntos de ferramentas: } \\
\text { - Estados finais: quadro de uma indústria em um ponto particular do } \\
\text { tempo, escritos tipicamente em conjuntos de quatro ou cinco. } \\
\text { - Eventos: uma tendência pode ser desagregada em uma série de } \\
\text { eventos. Ex.: computadores (tendência de serem menores, mais } \\
\text { rápidos e mais baratos } \rightarrow \text { abarca numerosos eventos: quão pequenos, }\end{array}$ & $\begin{array}{l}\text { - O futuro é } \\
\text { contingente e } \\
\text { moldado pela ação } \\
\text { de vários } \\
\text { participantes; } \\
\text { - Na maioria das }\end{array}$ \\
\hline
\end{tabular}




\begin{tabular}{|c|c|c|}
\hline & $\begin{array}{l}\text { quão rápidos e quão mais baratos serão em algum ponto do futuro. } \\
\text { Uso de workshops, com etapas bem definidas: } \\
\text { 1. Antes - criação dos estados finais e dos eventos; } 2 \text {. Explicitação do } \\
\text { modelo mental vigente - cenários de sabedoria convencional; } 3 \text {. } \\
\text { Mapeamento dos estados finais; participantes são divididos em } \\
\text { grupos; } 4 \text {. Construção dos cenários a apresentação para o grupo; } 5 \text {. } \\
\text { Análise dos pontos comuns e divergentes para os cenários; } 6 \text {. Escolha } \\
\text { do estado final mais desejável; } 7 \text {. Mapeamento da direção estratégica. }\end{array}$ & $\begin{array}{l}\text { indústrias, } \\
\text { esforços para } \\
\text { conseguir } \\
\text { vantagens } \\
\text { competitivas irão } \\
\text { causar mudanças } \\
\text { estruturais; } \\
\text { - David Mason. }\end{array}$ \\
\hline $\begin{array}{l}\text { Battelle } \\
\text { Memorial } \\
\text { Institute }\end{array}$ & $\begin{array}{l}\text { 1. Definição da estrutura do assunto a ser pesquisado; } 2 \text {. Identificação } \\
\text { e estruturação das áreas de influência sobre o assunto; } 3 \text {. Definição } \\
\text { dos descritores, com a lógica de cada descritor e atribuição de } \\
\text { probabilidades iniciais de ocorrência a cada estado dos descritores; } 4 \text {. } \\
\text { Preencher a Matriz de Impacto Cruzado com as probabilidades } \\
\text { identificadas na etapa } 3 \text { e rodar o programa BASICS; } 5 \text {. Seleção dos } \\
\text { cenários para estudo mais detalhado e elaboração da narrativa dos } \\
\text { mesmos; } 6 \text {. Introdução de eventos de baixa probabilidade, mas com } \\
\text { alto impacto, e conduzir análise de sensibilidade com o propósito de } \\
\text { analisar os seus efeitos; } 7 \text {. Elaboração das projeçães decorrentes dos } \\
\text { cenários e avaliação das suas implicações para a empresa. }\end{array}$ & $\begin{array}{l}\text { - Baseado no } \\
\text { método de Análise } \\
\text { de Impacto } \\
\text { Cruzado; } \\
\text { - Uso de software } \\
\text { BASICS (Battelle } \\
\text { Scenario Inputs to } \\
\text { Corporate } \\
\text { Strategy). }\end{array}$ \\
\hline $\begin{array}{l}\text { Análise } \\
\text { Prospectiva }\end{array}$ & $\begin{array}{l}\text { 1. Análise do problema e delimitação do sistema; } 2 \text {. Diagnóstico da } \\
\text { empresa; } 3 \text {. Análise estrutural; } 4 \text {. Dinâmica da empresa no ambiente; } \\
\text { 5. Cenários ambientais; } 6 \text {. Identificação das estratégias; } 7 \text {. Avaliação } \\
\text { das estratégias; } 8 \text {. Seleção das estratégias; 9. Planos de ação e } \\
\text { monitoração da estratégia. }\end{array}$ & $\begin{array}{l}\text { Aproximação } \\
\text { entre análise } \\
\text { prospectiva e } \\
\text { estratégia; } \\
\text { - Michel Godet. }\end{array}$ \\
\hline $\begin{array}{l}\text { Comprehensive } \\
\text { Situation } \\
\text { Mapping }\end{array}$ & $\begin{array}{l}\text { Duas etapas: 1. Fase divergente: a visão individual de cada tomador } \\
\text { de decisão sobre a natureza e estrutura da situação estratégica é } \\
\text { diagramada separadamente, sem a influência da idéia dos outros } \\
\text { participantes do processo; } 2 \text {. Fase convergente: os participantes do } \\
\text { processo interagem em um debate com apresentações dos diagramas } \\
\text { desenvolvidos individualmente, análise das hipóteses mais e menos } \\
\text { importantes e uma possível consolidação das idéias. }\end{array}$ & \begin{tabular}{lr}
\multicolumn{1}{c}{ Considera } & os \\
impactos & da \\
ocorrência \\
simultânea \\
recíproca \\
variáveis; das \\
- Não atribui \\
probabilidades; \\
- Mapeamento \\
cognitivo com a \\
integração com \\
um sistema \\
computadorizado.
\end{tabular} \\
\hline $\begin{array}{ll}\text { Análise } & \text { do } \\
\text { Impacto } & \text { de } \\
\text { Tendências } & \end{array}$ & $\begin{array}{l}\text { Três etapas: 1. Preparação: a) definição do foco - questões que } \\
\text { precisam ser respondidas para definir os limites dos cenários a serem } \\
\text { criados; b) mapeamento das forças motrizes que têm maior } \\
\text { capacidade de moldar o futuro do setor. 2. Desenvolvimento: a) } \\
\text { construção do espaço do cenário com a classificação dos vários } \\
\text { estados futuros em função das forças motrizes; b) seleção dos } \\
\text { cenários a serem detalhados; c) detalhamento dos cenários, } \\
\text { relacionando as tendências e os eventos necessários para chegar a } \\
\text { cada um dos estados finais. 3. Documentação e utilização: a) } \\
\text { documentação, compreendendo quadros e narrativas que descrevam a } \\
\text { história representada em cada cenário; b) comprovação das } \\
\text { implicações de cada cenário - quão diferentes serão as decisões sobre } \\
\text { os negócios em função de cada tipo de cenário. }\end{array}$ & $\begin{array}{l}\text { - Combina séries } \\
\text { temporais e } \\
\text { econometria com } \\
\text { fatores } \\
\text { qualitativos; } \\
\text { - Força o usuário a } \\
\text { identificar } \\
\text { explicitamente os } \\
\text { fatores de impacto } \\
\text { e avaliar tanto sua } \\
\text { probabilidade de } \\
\text { ocorrência como } \\
\text { sua importância. }\end{array}$ \\
\hline $\begin{array}{l}\text { Decision } \\
\text { Strategies } \\
\text { International }\end{array}$ & $\begin{array}{l}\text { 1. Definição do escopo: envolve a definição do horizonte de tempo } \\
\text { ao qual os cenários se referem e a definição do escopo de análise, as } \\
\text { matérias sobre as quais os cenários são elaborados. 2. Identificação } \\
\text { dos principais interessados (stakeholders): pessoas que tenham } \\
\text { interesse nas matérias dos cenários, que possam ser afetadas por eles } \\
\text { e que podem influenciá-los. 3. Identificação de tendências básicas: } \\
\text { quais tendências políticas, econômicas, sociais, tecnológicas, legais e } \\
\text { da indústria são certas para afetar as matérias identificadas no passo } \\
\text { 1? 4. Identificação de incertezas-chave: quais eventos, cujos }\end{array}$ & $\begin{array}{l}\text { - Lógica Intuitiva; } \\
\text { - Paul Shoemaker. }\end{array}$ \\
\hline
\end{tabular}




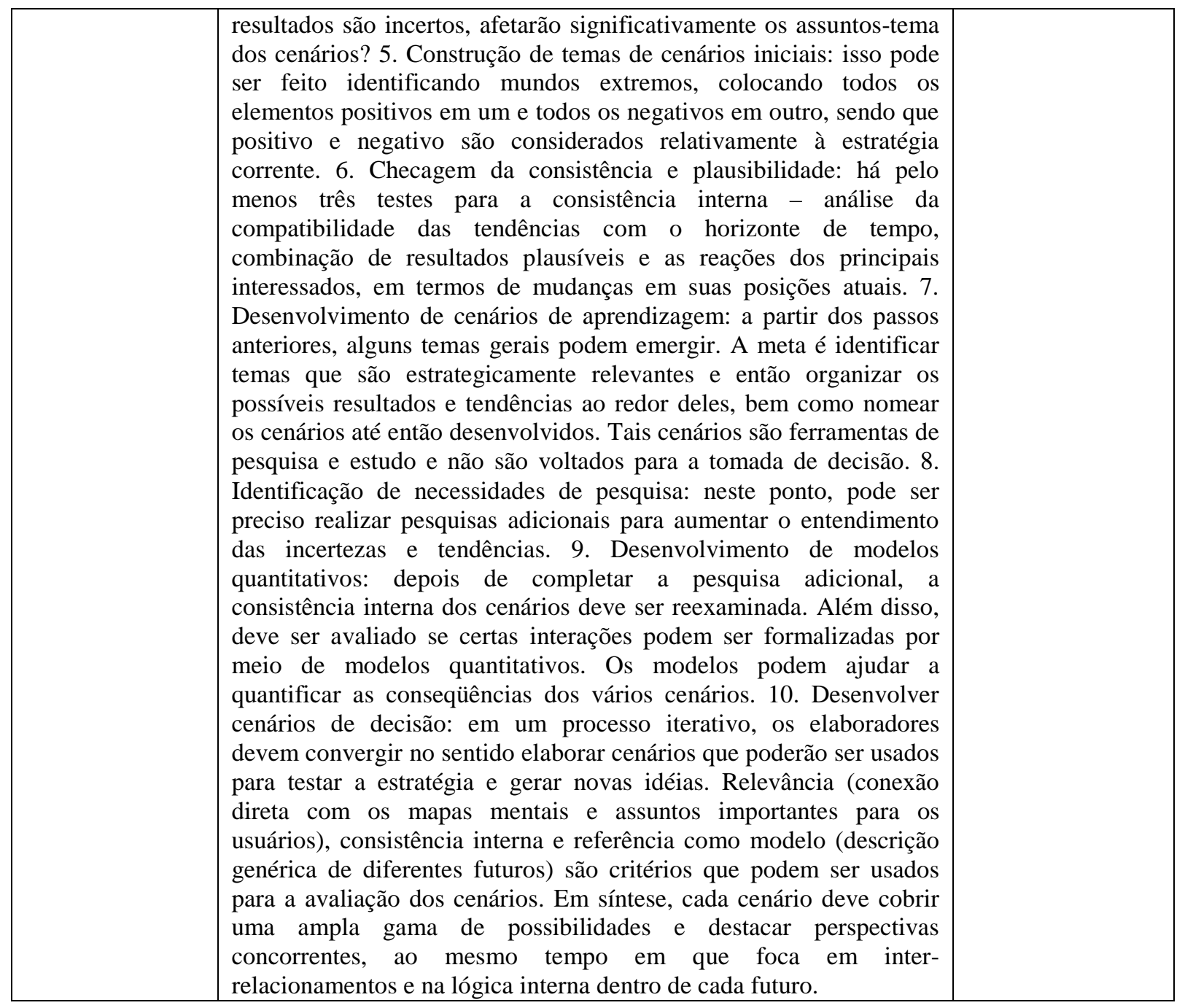

Quadro 11 - Métodos para elaboração de cenários

Fonte: adaptado de Boaventura, Costa e Fischmann (2005)

Segundo Wright e Spers (2006), cenários podem ser elaborados segundo sete etapas fundamentais, sendo que diferentes técnicas compõem o conjunto metodológico utilizado. Os autores descrevem como etapas: definição do escopo e objetivos dos cenários; identificação das variáveis, tendências e eventos fundamentais; estruturação das variáveis dos cenários; projeção dos estados futuros das variáveis e sua probabilidade de ocorrência; identificação de temas motrizes dos cenários; montagem de uma matriz morfológica para cada cenário; e redação e validação dos cenários.

1. Definição do escopo e objetivos dos cenários: caracterização do escopo dos cenários e caracterização das decisões a apoiar. definição do escopo, decisões relevantes, os atores centrais e grupos de interesse (stakeholders), a abrangência geográfica dos cenários e o horizonte temporal. 
2. Identificação das variáveis, tendências e eventos fundamentais: identificar as variáveis fundamentais, considerando os stakeholders e outros pontos relevantes para os cenários futuros.

3. Estruturação das variáveis dos cenários, identificando: tendências pesadas e fatores invariantes; eventos incertos e "fatos portadores do futuro"; e relações de causa e efeito entre as variáveis, identificando variáveis causais, intermediárias e resultantes.

4. Projeção dos estados futuros das variáveis e sua probabilidade de ocorrência: projeções qualitativas de dois e quatro estados futuros por variável; e estimativas de probabilidades de ocorrência dos estados futuros identificados.

5. Identificação de temas motrizes dos cenários; são definidos temas distintos para cada cenário, nesse caso com as seguintes características: um cenário mais provável que considera as forças históricas continuando a agir como no passado; dois cenários exploratórios contrastados que consideram o desenvolvimento de temas ou eventos marcantes, direcionadores do ambiente futuro; e um cenário normativo. De caráter prescritivo, esse cenário deve apresentar uma situação factível e desejada.

6. Montagem de uma matriz morfológica para cada cenário: a matriz morfológica é utilizada para combinar de maneira consistente os estados futuros previstos para cada variável dos cenários, com base na estrutura dessas variáveis.

7. Redação e validação dos cenários: o detalhamento dos cenários, com a descrição de sua evolução e a explicitação das relações e seqüências de causa e efeito entre as variáveis consideradas, assim como análise da consistência interna, da plausibilidade de cada cenário e da relevância das variáveis dos cenários para as decisões a serem tomadas; e a validação dos cenários com especialistas ou grupos de interesse, por meio da apresentação e discussão destes; é a etapa final de elaboração.

A premissa desta abordagem é de que os cenários devem ser elaborados não para "acertar" previsões do futuro, mas sim para melhorar a base de informações e a compreensão sobre decisões que precisam ser tomadas no presente para assegurar objetivos futuros. 


\section{PROCEDIMENTOS METODOLÓGICOS}

Este trabalho propõe a seguinte questão de pesquisa: Quais são as implicações para o desenvolvimento de capacidades dinâmicas pelas destilarias brasileiras de possíveis cenários do mercado internacional de etanol em 2020?

Para respondê-la foi realizado um estudo exploratório, em uma abordagem qualitativa e de natureza aplicada.

Conforme afirma Selltiz et al. (2004), os estudos exploratórios são conduzidos quando se pretende ganhar familiaridade com o fenômeno que se deseja estudar, ou para definir problemas que ainda não são muito claros, assim como criar novas hipóteses a serem testadas em estudos subseqüentes. Collis e Hussey (2005) complementam afirmando que o uso da pesquisa exploratória justifica-se por haver poucos estudos anteriores para o problema de pesquisa em questão, onde o pesquisador visa buscar padrões, idéias, ou hipóteses.

Segundo Richardson (2009), o método qualitativo difere, em princípio, do quantitativo à medida que não emprega um instrumental estatístico como base do processo de análise de um problema. Não pretende numerar ou medir unidades ou categorias homogêneas. Para o autor, a abordagem qualitativa de um problema justifica-se por ser uma forma adequada para entender a natureza de um fenômeno social. Em princípio, as investigações que se voltam para uma análise qualitativa têm como objeto situações complexas ou estritamente particulares. Os estudos que empregam uma metodologia qualitativa podem descrever a complexidade de um determinado problema, analisar a interação de certas variáveis, compreender e classificar processos dinâmicos vividos por grupos sociais, contribuir no processo de mudança de determinado grupo e possibilitar, em maior nível de profundidade, o entendimento das particularidades do comportamento dos indivíduos.

Segundo Cooper e Schindler (2003), a pesquisa aplicada tem uma ênfase prática na solução de problemas. A natureza de solução de problemas da pesquisa aplicada significa que ela é conduzida para revelar respostas para questões específicas relacionadas à ação, desempenho ou necessidades políticas.

Para a solução do problema de pesquisa proposto, foram realizadas duas etapas. 
Inicialmente foram elaborados cenários para o mercado internacional de etanol em 2020. Para tanto, utilizou-se o método de elaboração de cenários proposto por Wright e Spers (2006), que tomou por base a contextualização do cenário atual do mercado internacional de etanol feita a partir de dados primários e secundários. Dados primários foram coletados por meio de entrevista com um representante da UNICA. Dados secundários foram coletados por meio de pesquisa bibliográfica, os quais são descritos na seção "Contextualização: biocombustíveis e etanol" deste trabalho. Segundo Gil (2009), pode-se definir entrevista como a técnica em que o investigador se apresenta frente ao investigado e lhe formula perguntas, com o objetivo de obtenção dos dados que interessam á investigação. Enquanto técnica de coleta de dados, a entrevista é bastante adequada para a obtenção de informações acerca do que as pessoas sabem, crêem, esperam, sentem ou desejam, pretendem fazer, fazem ou fizeram, bem como acerca de suas explicações ou razões a respeito de coisas precedentes (SELLTIZ ET AL., 1967 APUD GIL, 2009). Especificamente, foi realizada uma entrevista dirigida, a qual, segundo Richardson (2009), desenvolve-se a partir de perguntas precisas, pré-formuladas e com uma ordem preestabelecida (conforme mostra o Anexo 1).

Em seguida, foi realizada uma pesquisa de campo com uma empresa do setor de etanol, tendo em vista analisar a consistência dos cenários elaborados e explorar empiricamente o conceito de capacidades dinâmicas. Assim, foi realizado um estudo de caso com uma destilaria localizada em Jacarezinho - Paraná. Segundo Yin (2005), o estudo de caso é uma forma de se fazer pesquisa social empírica ao investigar-se um fenômeno atual dentro do contexto da vida real, onde as fronteiras entre o fenômeno e o contexto não são claramente definidas.

A escolha do caso deu-se por critério de conveniência e acessibilidade. Os dados coletados são de origem primária e foram coletados por meio de duas entrevistas (conforma mostra o Anexo 2) com gestores da empresa (presidente e gerente comercial). Para analisar os dados, utilizou-se análise de conteúdo, que, segundo Richardson (2009), é particularmente utilizada para estudar material de tipo qualitativo. Para Bardin (1979), a análise de conteúdo é um conjunto de técnicas de análise das comunicações visando obter, através de procedimentos sistemáticos e objetivos de descrição do conteúdo das mensagens, indicadores (quantitativos ou não) que permitam inferir conhecimentos relativos às condições de produção/recepção (variáveis inferidas) dessas mensagens. 


\section{RESULTADOS E DISCUSSÃO}

Esta seção apresenta os resultados e discussão do trabalho. Inicialmente, é apresentada a visão do mercado internacional de etanol em 2020 extraída da entrevista em profundidade com um representante da União da Indústria da Cana-de-Açúcar - UNICA. Em seguida, são elaborados possíveis cenários do mercado internacional em 2020, os quais partem do cenário atual e trabalham incertezas-chave para a configuração final de como o futuro poderá ser. Tais cenários são elaborados com base na metodologia proposta por Wright e Spers (2006). Tão importante quanto obter visões de como o futuro poderá ser é discutir as implicações de tais futuros possíveis para as estratégias empresarias. Assim, os cenários elaborados são utilizados para discutir as implicações para o desenvolvimento de capacidades dinâmicas pelas empresas de etanol nos próximos 10 anos.

\subsection{Mercado internacional de etanol em 2020 - UNICA}

A União da Indústria de Cana-de-Açúcar á a maior organização representativa de açúcar e etanol do Brasil. Sua criação em 1997 resultou da fusão de diversas organizações setoriais do estado de São Paulo, após a desregulamentação do setor no País. A organização se expressa e atua em sintonia com os interesses dos produtores de açúcar, etanol e bioeletricidade tanto no Brasil quanto ao redor do mundo. As 119 empresas associadas a UNICA são responsáveis por de $50 \%$ do etanol e $60 \%$ do açúcar produzidos no Brasil.

O domínio técnico da UNICA compreende as áreas de meio ambiente, energia, tecnologia, comércio exterior, responsabilidade social corporativa, sustentabilidade, legislação, economia e comunicação.

No final de 2007, a UNICA abriu seu primeiro escritório internacional nos Estados Unidos e em 2008 na Europa, como parte de sua política de prover informações detalhadas e atualizadas sobre as contribuições sócio-econômicas e ambientais do setor de açúcar, etanol e bioeletricidade a interlocutores como consumidores, governos, organizações nãogovernamentais, empresas e mídia. 
Na visão da organização há a percepção de grandes oportunidades para o estabelecimento de um mercado internacional para o etanol, tendo destaque o mercado dos Estados Unidos e da Europa no ponto de vista das exportações do Brasil.

Atualmente, o mercado americano com o Renewable Fuels Standard Program prevê um consumo mandatório de 36 bilhões de galões de etanol até 2022 - o que representará aproximadamente 140 bilhões de litros. Portanto, é um mercado atraente para o Brasil. Entretanto, para que seja economicamente viável atuar nesse mercado, será necessário superar dificuldades em dois pontos principais: barreiras tarifárias e balanço de $\mathrm{CO}_{2}$.

Vigoram duas tarifas para que o etanol brasileiro entre nos Estados Unidos. A primeira é a tarifa primária que está prevista em acordo da Organização Mundial do Comércio, onde uma tarifa de $2,5 \%$ é cobrada sobre o etanol importado. A segunda tarifa, ou tarifa secundária, corresponde a 54 cents por galão, ou 19 cents por litro, a qual teve como origem a isenção tributária para os distribuidores de gasolina. Quando foi criada a tarifa, os distribuidores de gasolina tinham uma isenção de 54 cents por galão. Para evitar que esse benefício fosse auferido por produtores de fora do país, eles criaram a tarifação de 54 cents por galão para o etanol importado. Ou seja, ao mesmo tempo em que há uma isenção para o etanol produzido internamente, há uma taxação para o etanol importado, tendo em vista incentivar a produção local. A questão atualmente, e que deverá ser trabalhada no futuro, é que o governo foi diminuindo essa isenção, e hoje está em 45 cents por galão, mas não diminuíram a tarifação de importação que continua em 54 cents por galão. Tal tarifa diminui de maneira significativa a competitividade do etanol brasileiro, pois podem representar de 30 a $40 \%$ do preço do combustível. Nesse contexto, nos próximos anos será necessária a atuação do Brasil no sentido de derrubá-la, tendo oposições de lobbies americanos dos produtores de milho que querem manter essa tarifa para a proteção de seu mercado interno. Atualmente, o Brasil já está pleiteando pelo menos a redução para 45 cents por galão. Há uma tentativa de articulação com outros setores que tem interesse na queda da barreira, como, por exemplo, os consumidores de milho, que precisam do produto para alimentação animal.

Quanto à redução de $\mathrm{CO}_{2}$, o mercado americano está dividido de acordo com a capacidade dos diferentes tipos de matéria-prima para produzir etanol para fazê-lo. O etanol está classificado em 3 tipos: o etanol convencional, o avançado e o celulósico. O etanol convencional é capaz de reduzir o $\mathrm{CO}_{2}$ em até $20 \%$ comparado com a gasolina. O etanol de 
milho se enquadra nessa categoria e tem um limite máximo de consumo de $40 \%$ em 2022. Para os outros $60 \%$, será necessário adotar o etanol avançado, que chega a reduzir $50 \%$ a emissão de $\mathrm{CO}_{2}$ comparado com a gasolina, e o etanol celulósico que consegue diminuir $60 \%$ as emissões quando comparado com a gasolina. A incerteza envolvida nesse tema é que esses critérios estão sendo revistos com a utilização de duas metodologias. A primeira é a análise do ciclo de vida, na qual é observado todo o processo de produção e consumo do etanol - desde o plantio, transporte, industrialização, queima do combustível pelo automóvel. A segunda metodologia são os modelos de uso indireto da terra, na qual são avaliados todos os impactos quando há o aumento da produção de biocombustíveis, em termos do que acontece com as outras culturas que são substituídas - se para continuarem a ser plantadas essas outras culturas induzem o desmatamento, liberando o $\mathrm{CO}_{2}$ que estava estocado no solo. Atualmente, essas análises estão sendo feitas e o Brasil poderá se beneficiar atuando nas parcelas de etanol avançado e celulósico.

Assim, nos próximos anos o mercado americano é visto como grande oportunidade, com o maior plano de etanol do mundo, mas ao mesmo tempo com algumas dificuldades, seja no ponto de vista de barreiras tarifárias, seja no ponto de vista de garantir que o cálculo que eles estão fazendo para verificar o quanto que o etanol brasileiro produz de $\mathrm{CO}_{2}$ seja correto.

O mercado europeu é o segundo maior mercado hoje e poderá ser atrativo no futuro. A diretiva da União Européia determina que até 2020 todos os 27 países do bloco devem utilizar $10 \%$ de combustíveis renováveis em seus combustíveis. É importante ressaltar que não necessariamente o etanol será utilizado, pois outras fontes estarão concorrendo, como a eletricidade. Nas estimativas da UNICA, na hipótese de substituição da gasolina por etanol, poderá haver um mercado de 14 ou 15 bilhões de litros até 2020. Apesar de representar $10 \%$ do mercado americano de 2022, o mercado pode ser considerado grande, pois representa quase o consumo total de etanol no Brasil. Além disso, o Brasil poderá ter uma maior possibilidade de complementação do etanol local, pois a União Européia não tem um programa como o etanol de milho americano - que pode produzir em escalas muito maiores que o etanol de beterraba e o de trigo da União Européia.

Entretanto, existem dificuldades a serem superadas nos próximos anos. A primeira é a barreira tarifária de 19 cents de euro por litro, sobre a qual será necessário discutir nas Rodadas de Doha. A questão é complexa, pois além da tarifa ser maior que a americana, ela 
está registrada no compromisso em Doha e depende das negociações na Rodada. O segundo problema são as barreiras não-tarifárias. Atualmente, quase todos os países da União Européia estão desenvolvendo fóruns para certificação. A questão será se não houver um padrão único para certificação, o que dificultará a atuação do Brasil no mercado europeu. O desafio para o futuro será alcançar convergência entre os diferentes esquemas de certificação.

Quanto ao terceiro mercado, o asiático, a visão da UNICA é que se trata de um mercado que tem bastante perspectiva, mas não em estado tão desenvolvido como nos Estados Unidos e na União Européia. Na região, pode ser mencionada a China tem alguns programas em algumas províncias - normativas de mistura entre 5 e $10 \%$ de etanol. Outros países também estão desenvolvendo programas. Trata-se de países em condição de produzir etanol no leste asiático e no sudeste asiático, como, por exemplo, Tailândia, Indonésia e Filipinas, que já produzem cana-de-açúcar e mandioca. O programa na Tailândia, por exemplo, prevê parte da produção de etanol através da mandioca, e estão conseguindo alcançar competitividade com isso. Assim, a visão do mercado asiático é que estão surgindo programas na região que poderão gerar uma escala de consumo importante para o Brasil.

Segundo o entrevistado, a UNICA acredita que o crescimento do consumo de biocombustíveis não ocorrerá naturalmente como acontece com outras commodities, pois este não é um mercado que nasce espontaneamente e cresce espontaneamente. Nos próximos anos, sua expansão se dará a partir de políticas públicas, como nos casos de misturas obrigatórias que o governo impõe. Tais políticas continuarão a atuar em consonância com tendências e necessidades mais amplas da sociedade, principalmente no que se refere às preocupações com sustentabilidade e busca por segurança energética.

A formação de um mercado internacional é um objetivo de longo prazo desejável. Para isso, será necessário ter mecanismos que gerem liquidez para esses mercados, como mercados futuros e contratos de longo prazo. Será necessário ter uma referência de preços e um conjunto maior de informações de oferta e demanda.

Outra questão é a incerteza da demanda. Ainda não há sinais claros de quanto os mercados querem, e em que ritmo crescerão. Como resposta, os mercados potencialmente produtores se retraem em seus investimentos. Por outro lado, muitos dos países demandantes, principalmente os países desenvolvidos, não são mais ambiciosos nas propostas de seus 
programas, porque ficam receosos de dependerem somente da produção brasileira para suprir sua demanda por etanol. Assim, mercados demandantes não dão um sinal claro porque ainda não vêem uma capilaridade muito grande da oferta, configurando um impasse no desenvolvimento do mercado.

$\mathrm{Na}$ visão da UNICA, o mercado produtor brasileiro está olhando muito fortemente para o mercado internacional e está procurando se adequar às exigências, principalmente no que se refere à certificação dos biocombustíveis.

Outra questão importante são os investimentos que começam a se delinear em relação aos transportes. Atualmente, o mercado consumidor é basicamente concentrado em São Paulo, Minas Gerais, Paraná e Rio de Janeiro. Entretanto, a expansão da cana-de-açúcar está se dando cada vez mais longe dessas regiões, como Goiás e Mato Grosso do Sul. Como esse mercado não terá um consumo local importante, a produção terá que ser direcionada para o mercado internacional - com implicações para os custos de transporte para os portos. Assim, será necessário viabilizar a construção de alcooldutos, de tal forma que se aumente a competitividade da produção para exportação desses estados emergentes.

Para a UNICA, além do Brasil, nos próximos anos outros países têm potencial para entrar no mercado internacional como fornecedores de etanol. Diversos países da África têm condições agroclimáticas parecidas com o Brasil - como Moçambique que está na mesma faixa de São Paulo. Em princípio são países com boa perspectiva, além de estarem bem próximos dos consumidores da Ásia, por exemplo. Entretanto, apenas as condições climáticas não serão suficientes para lançar um país como fornecedor, pois $60 \%$ dos custos da produção de etanol estão na parte agrícola. Nesse ponto, o Brasil tem vantagens, pois é bem desenvolvido nas tecnologias de manejo agrícola. Além disso, os países africanos não dispõem de mão-de-obra qualificada, infra-estrutura e ambiente institucional estabilizado. Por outro lado, a possibilidade de produção da bioeletricidade para gerar energia no campo pode ser um estímulo adicional para países africanos, e também da América Central, produzirem etanol.

Segundo a UNICA, um fator que será importante para o Brasil será a aliança com os Estados Unidos, o que seria muito promissor. O ponto fundamental da aliança será a cooperação técnica, pois irá se desenvolver na linha de novas tecnologias e, dentre elas, a mais importante que é o etanol de segunda geração ou etanol celulósico. Além disso, será importante ampliar o 
entendimento entre os países para que se trabalhe um programa de segurança energética nas Américas, no qual Estados Unidos e Brasil serão os principais players e poderão fazer parcerias técnicas nas áreas agrícola e industrial com outros países em condições de produzir cana-de-açúcar. Ainda que em fase embrionária, um ponto que merece ser observado nos próximos anos é a iniciativa da União Européia de firmar parcerias com países da África.

No Brasil, o mercado de etanol foi aquecido com a introdução dos carros flexfuel. Assim, buscou-se levantar a opinião da UNICA quanto a possibilidade da introdução e expansão da tecnologia flex em outros países. Dois fatores limitantes foram identificados. O primeiro é que, para eles, a indústria automobilística não tem interesse em ter tecnologias diferentes em diferentes partes do mundo - o ideal é que elas possam produzir em determinado país e exportar o mesmo produto para outros países. O segundo ponto é a questão dos canais de distribuição, pela necessidade de criar uma rede que possibilite a entrega do produto para o consumidor final.

Por fim, foi levantado pela UNICA que merecem atenção os novos usos que estão sendo desenvolvidos para o etanol e poderão aumentar a demanda pelo biocombustível nos próximos 10 anos, como a motocicleta flexfuel, o uso em aviões de pulverização agrícola, os bioplásticos. Existem estudos para aviões comerciais de curta distância e outras pesquisas em etanol para ônibus movido a diesel.

\subsection{Desenvolvimento de cenários possíveis em 2020}

Wright e Spers (2006) afirmam que elaborar cenários não é um exercício de predição, mas sim um esforço de fazer descrições plausíveis e consistentes de situações futuras possíveis, apresentando os condicionantes do caminho entre a situação atual e cada cenário futuro, destacando os fatores relevantes às decisões que precisam ser tomadas.

Para os mesmos autores, cenários podem ser elaborados segundo sete etapas fundamentais, sendo que diferentes técnicas compõem o conjunto metodológico utilizado. Os autores definem as seguintes etapas: definição do escopo e objetivos dos cenários; identificação das variáveis, tendências e eventos fundamentais; estruturação das variáveis dos cenários; projeção dos estados futuros das variáveis e sua probabilidade de ocorrência; identificação de 
temas motrizes dos cenários; montagem de uma matriz morfológica para cada cenário; e redação e validação dos cenários.

A seguir são descritas e aplicadas as etapas propostas.

\section{Definição do escopo e objetivos dos cenários}

A primeira etapa é a caracterização do escopo dos cenários e caracterização das decisões a apoiar, os atores centrais e grupos de interesse (stakeholders), a abrangência geográfica dos cenários e o horizonte temporal.

Neste trabalho, o escopo dos cenários é a configuração futura do mercado internacional de etanol. O horizonte de tempo é 2020, uma vez que grande parte da regulamentação que indica expansão da demanda do mercado internacional baseia-se neste ano. As questões que se pretende entender melhor estão relacionadas ao perfil da demanda e perfil da produção, além dos impactos das decisões tomadas na esfera político-institucional e que afetam os players do mercado. O perfil da demanda será influenciado principalmente pela adição mandatória de etanol à gasolina, questão que tem evoluído nos últimos anos, principalmente nos Estados Unidos e na União Européia. O aumento da conscientização dos países e preocupações com a redução das emissões de dióxido de carbono na atmosfera também afetará positivamente a demanda, uma vez que o etanol é, atualmente, um combustível economicamente viável e em condições de ser ofertado. Acompanha a viabilidade econômica os avanços tecnológicos que tem sido realizados nos complexos agroindustriais. Na agricultura, a modernização dos processos e a melhoria genética das cultivares têm aumentado a produtividade no campo, o que impacta diretamente nos custos de produção. $\mathrm{Na}$ indústria, as destilarias têm realizado diversos avanços nos processos produtivos para fabricação de etanol. O perfil da oferta dependerá, em grande parte, justamente das capacitações tecnológicas dos países em condições de produzir etanol, como Estados Unidos e Brasil, com destaque para este último em termos de competitividade. Soma-se ao fator tecnológico, as vantagens comparativas, como condição de clima e disponibilidade de solo. Cabe ressaltar que a simples indisponibilidade de terras não elimina a possibilidade de um país entrar nesse mercado como produtor. Estratégias para driblar essa deficiência podem ser adotadas, como o arrendamento de terras na África. Além disso, a própria capacitação tecnológica pode reduzir vantagens de clima e solo. O aumento da produtividade do etanol produzido por hectare cultivado é um 
indicador de que, mesmo com menos terra disponível, será possível à um país ser ofertante do produto. Há que se considerar como ponto fundamental na configuração futura desse mercado a geopolítica mundial que será estabelecida, em termos de acordos entre os países para oferecer condições de compra e venda do produto no mercado internacional. Condições que dependerão de negociações em relação à tarifação para entrada do produto e o estabelecimento de um padrão mundial para o etanol. Nesta seara de geopolítica mundial poderão ocorrer acordos entre os países e indícios desta possibilidade já existem, haja visto o entendimento entre Brasil e Estados Unidos expressando a intenção de cooperação e difusão de biocombustíveis em uma estratégia de três níveis, envolvendo acordos bilaterais e multilaterais e, também, intenções globais.

No que diz respeito aos stakeholders, pode-se apontar participantes do setor empresarial (destilarias independentes e grupos empresariais produtores de etanol), o governo (Ministério do Desenvolvimento, Indústria e Comércio Exterior, Ministério da Agricultura, Pecuária e Abastecimento, Ministério de Ciência e Tecnologia), institutos de pesquisa (Embrapa, Centro de Tecnologia Canavieira) e entidades de defesa dos interesses do setor (UNICA).

\section{Identificação das variáveis, tendências e eventos fundamentais}

Uma vez definido o escopo, deve-se identificar as variáveis fundamentais, tendências e eventos fundamentais. Para tanto, procedeu-se uma revisão de literatura em diferentes fontes bibliográficas - artigos acadêmicos, estudos técnicos, estudos setoriais, reportagens de revistas especializadas, dissertações e teses. As informações concernentes ao levantamento de tendências e eventos fundamentais estão descritas neste trabalho no capítulo "Contextualização: biocombustíveis e etanol”.

Com base na pesquisa, foram selecionadas as seguintes variáveis para compor os cenários:

- Preocupação ambiental e mudanças climáticas;

- Segurança energética do planeta;

- Regulamentação interna dos países;

- Capacitação tecnológica para produção de etanol;

- Estabelecimento de um padrão internacional para o produto;

- Política comercial dos países; 
- Movimentos contrários aos biocombustíveis;

- Desenvolvimento tecnológico na indústria automobilística;

- Desenvolvimento tecnológico em outras indústrias de transporte;

- Preços internacionais do petróleo;

- Preços internacionais do açúcar.

\section{Estruturação das variáveis dos cenários}

Após serem identificadas, as variáveis devem ser estruturadas, identificando: tendências pesadas e fatores invariantes; eventos incertos e "fatos portadores do futuro"; e relações de causa e efeito entre as variáveis, identificando variáveis causais, intermediárias e resultantes.

Assim, as variáveis descritas no item 2 podem ser estruturadas da seguinte forma, onde a seta indica a relação do tipo "afeta":

Preocupação com o

meio ambiente e

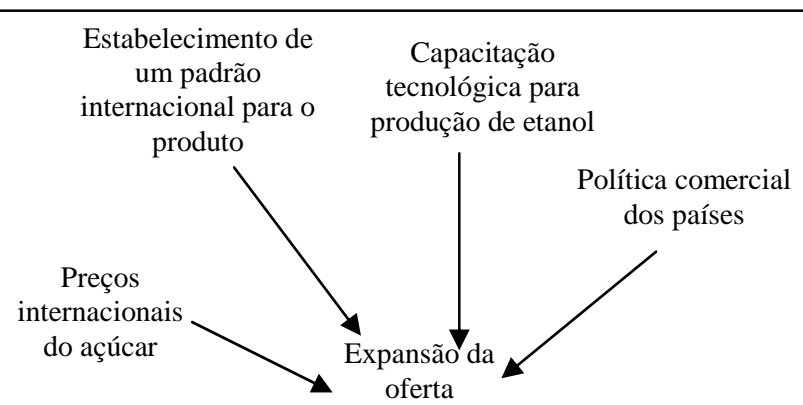

mudanças climáticas
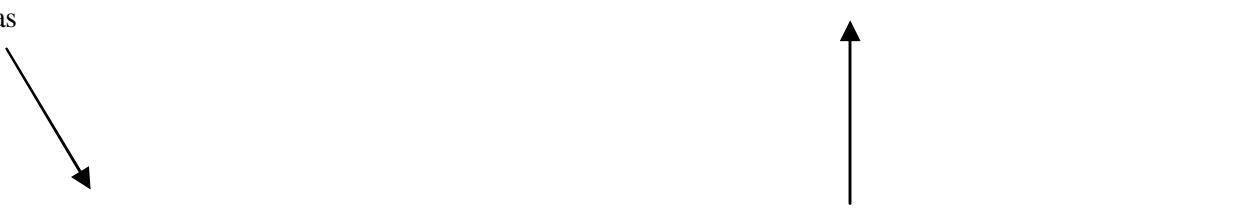

Regulamentação interna dos países

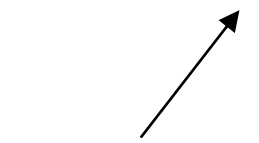

Segurança energética

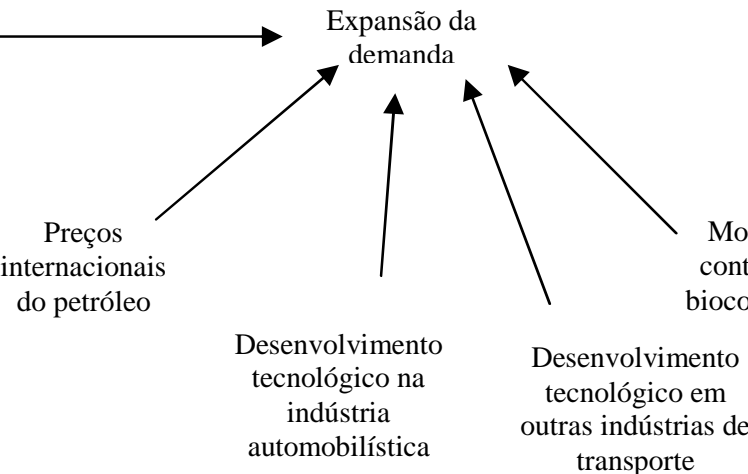

Figura 4 - Estruturação das variáveis

Fonte: o autor 
- Preocupação ambiental e mudanças climáticas - essa pode ser considerada uma tendência pesada e tem motivado os países a reduzir a emissão de dióxido de carbono na atmosfera e comprometimentos têm sido realizados, como o Protocolo de Quioto. Uma das alternativas para a redução de emissões é a utilização de combustíveis mais "verdes" e o etanol entra nesse contexto por, comprovadamente, reduzir as emissões de $\mathrm{CO}_{2}$.

- Segurança energética do planeta - as estimativas apontam para a redução crescente das reservas de petróleo e a necessidade de haver energias alternativas. Busca-se também diminuir a dependência de países com grande instabilidade política e institucional, como é o caso dos países no Oriente Médio e Venezuela. A preocupação com a segurança energética influencia positivamente a expansão da produção e comércio do etanol. Há que se considerar que essa motivação de expansão ocorrerá no sentido de diversificar os países em condição de ofertar, para que não haja poder de mercado e dependência de alguns poucos players no abastecimento do mercado. Essa pode ser considerada uma tendência pesada.

- Regulamentação interna dos países - associada às preocupações ambientais e às mudanças climáticas está a regulamentação interna dos países que prevê um percentual de adição obrigatória de etanol à gasolina - ela afetará positivamente a demanda por etanol.

- Capacitação tecnológica para produção de etanol - a capacitação tecnológica será um determinante dos países em condição de atuar competitivamente na oferta do produto, envolvendo aspectos da tecnologia de produção dominante e da fonte de biomassa que será utilizada.

- Estabelecimento de um padrão internacional para o produto - essa força estabelecerá barreiras no comércio internacional, na medida em que criará um padrão que demandará dos países a capacidade de atender às exigências.

- Política comercial dos países - a política comercial externa, principalmente em termos de tarifação, afetará a dinâmica do comércio internacional, na medida em que políticas protecionistas poderão afetar a competitividade internacional dos players ofertantes. Nessa força também atuam acordos comerciais entre países para a cooperação na produção e abastecimento de etanol. 
- Movimentos contrários aos biocombustíveis - essa força será moldada fortemente pela interação da produção de alimentos e da produção de biocombustíveis, na medida em que commodities destinadas à alimentação estão sendo destinadas para a produção de etanol (como é caso do milho nos Estados Unidos).

- Desenvolvimento tecnológico na indústria automobilística - no Brasil principalmente o desenvolvimento de carros flex fuel impulsionaram o desenvolvimento da indústria de etanol na primeira década deste século. A evolução dos veículos em termos de fonte de combustível poderá afetar a demanda por etanol de forma incerta, uma vez que em outros países a tecnologia flex fuel não tem grande penetração.

- Desenvolvimento tecnológico em outras indústrias de transporte - existem alguns sinais de adoção de etanol como combustível em outros setores de transporte, como pequenos aviões agrícolas e motores que combinam diesel e etanol.

- Preços internacionais do petróleo - considerando que o etanol é um produto substituto da gasolina, as variações do preço do petróleo no mercado internacional afetam a demanda e oferta do produto. Preços altos impulsionaram a demanda por etanol; preços baixos terão efeitos contrários.

- Preços internacionais do açúcar: sendo o açúcar o principal produto a ser considerado no custo de oportunidade do etanol, seus preços devem ser considerados. Preços baixos impulsionam a produção de etanol; preços altos terão efeitos contrários.

\section{Projeção dos estados futuros das variáveis}

Depois de identificadas e estruturadas, devem ser realizadas projeções qualitativas de dois e quatro estados futuros por variável, conforme pode ser visto no Quadro 12, a seguir: 


\begin{tabular}{|c|c|c|c|c|}
\hline & Estado futuro 1 & Estado futuro 2 & Estado futuro 3 & Estado futuro 4 \\
\hline $\begin{array}{l}\text { Regulamentação interna } \\
\text { dos países }\end{array}$ & $\begin{array}{c}\text { Mantém } \\
\text { tendência de } \\
\text { adição } \\
\text { mandatória } \\
\end{array}$ & $\begin{array}{c}\text { Adição } \\
\text { mandatória tem } \\
\text { pequena } \\
\text { elevação } \\
\end{array}$ & $\begin{array}{l}\text { Adição } \\
\text { mandatória é } \\
\text { reduzida }\end{array}$ & $\begin{array}{c}\text { Adição mandatória } \\
\text { aumenta }\end{array}$ \\
\hline $\begin{array}{l}\text { Capacitação tecnológica } \\
\text { para produção de etanol }\end{array}$ & $\begin{array}{l}\text { Capacitação } \\
\text { tecnológica se } \\
\text { mantém nos } \\
\text { níveis atuais }\end{array}$ & $\begin{array}{l}\text { Existência de } \\
\text { acordos entre } \\
\text { parceiros } \\
\text { comerciais para } \\
\text { transferência de } \\
\text { tecnologia }\end{array}$ & $\begin{array}{c}\text { Bloco Europeu } \\
\text { lidera a } \\
\text { capacitação } \\
\text { tecnológica }\end{array}$ & $\begin{array}{l}\text { Brasil e Estados } \\
\text { Unidos lideram a } \\
\text { capacitação } \\
\text { tecnológica }\end{array}$ \\
\hline $\begin{array}{l}\text { Estabelecimento de um } \\
\text { padrão internacional para } \\
\text { o produto }\end{array}$ & $\begin{array}{c}\text { Países } \\
\text { estabelecem } \\
\text { padrões para } \\
\text { determinadas } \\
\text { características, } \\
\text { mas as } \\
\text { negociações } \\
\text { continuam }\end{array}$ & $\begin{array}{l}\text { Estabelecimento } \\
\text { de um padrão } \\
\text { entre parceiros } \\
\text { comerciais }\end{array}$ & $\begin{array}{l}\text { Países não } \\
\text { chegam a um } \\
\text { acordo sobre o } \\
\text { estabelecimento } \\
\text { de um padrão }\end{array}$ & $\begin{array}{l}\text { Estabelecimento de } \\
\text { um padrão único }\end{array}$ \\
\hline $\begin{array}{l}\text { Política comercial dos } \\
\text { países }\end{array}$ & $\begin{array}{l}\text { Países mantém } \\
\text { barreiras nos } \\
\text { patamares atuais }\end{array}$ & $\begin{array}{l}\text { Países aumentam } \\
\text { moderadamente } \\
\text { barreiras } \\
\text { tarifárias e não } \\
\text { tarifárias } \\
\end{array}$ & $\begin{array}{l}\text { Países reduzem } \\
\text { barreiras tarifárias } \\
\text { e não tarifárias }\end{array}$ & $\begin{array}{l}\text { Países aumentam } \\
\text { barreiras tarifárias e } \\
\text { não tarifárias }\end{array}$ \\
\hline $\begin{array}{l}\text { Movimentos contrários } \\
\text { aos biocombustíveis }\end{array}$ & $\begin{array}{l}\text { Países encontram } \\
\text { instabilidade na } \\
\text { oferta de } \\
\text { alimentos e } \\
\text { biocombustíveis }\end{array}$ & $\begin{array}{l}\text { Há } \\
\text { preponderância } \\
\text { da produção de } \\
\text { alimentos sobre } \\
\text { biocombustíveis }\end{array}$ & $\begin{array}{c}\text { Há } \\
\text { preponderância de } \\
\text { produção de } \\
\text { biocombustíveis } \\
\text { sobre alimentos }\end{array}$ & $\begin{array}{l}\text { Países conseguem } \\
\text { produzir } \\
\text { harmonicamente } \\
\text { alimentos e } \\
\text { biocombustíveis }\end{array}$ \\
\hline $\begin{array}{l}\text { Desenvolvimento } \\
\text { tecnológico na indústria } \\
\text { automobilística }\end{array}$ & $\begin{array}{l}\text { Carros flex fuel } \\
\text { mantém } \\
\text { tendência de } \\
\text { aprimoramento }\end{array}$ & $\begin{array}{c}\text { Outras } \\
\text { tecnologias } \\
\text { ganham } \\
\text { preponderância } \\
\text { sobre carros flex } \\
\text { fuel }\end{array}$ & $\begin{array}{l}\text { Há estagnação no } \\
\text { desenvolvimento } \\
\text { de carros flex fuel }\end{array}$ & $\begin{array}{l}\text { Há inovações } \\
\text { elevadas na } \\
\text { tecnologia flex fuel }\end{array}$ \\
\hline $\begin{array}{l}\text { Desenvolvimento } \\
\text { tecnológico em outras } \\
\text { indústrias de transporte }\end{array}$ & $\begin{array}{l}\text { Desenvolvimento } \\
\text { tecnológico } \\
\text { mantém os } \\
\text { patamares atuais }\end{array}$ & $\begin{array}{l}\text { Desenvolvimento } \\
\text { tecnológico } \\
\text { ocorre de forma } \\
\text { moderada }\end{array}$ & $\begin{array}{l}\text { Há estagnação do } \\
\text { desenvolvimento } \\
\text { tecnológico }\end{array}$ & $\begin{array}{c}\text { Há grande } \\
\text { desenvolvimento } \\
\text { tecnológico }\end{array}$ \\
\hline $\begin{array}{l}\text { Preços internacionais do } \\
\text { petróleo }\end{array}$ & $\begin{array}{l}\text { Preço mantém os } \\
\text { patamares atuais }\end{array}$ & $\begin{array}{c}\text { Preços têm } \\
\text { pequena } \\
\text { elevação }\end{array}$ & Preços caem & $\begin{array}{l}\text { Preços têm grande } \\
\text { elevação }\end{array}$ \\
\hline $\begin{array}{l}\text { Preços internacionais do } \\
\text { açúcar }\end{array}$ & $\begin{array}{l}\text { Preço mantém os } \\
\text { patamares atuais }\end{array}$ & $\begin{array}{l}\text { Preços têm } \\
\text { pequena } \\
\text { elevação }\end{array}$ & Preços caem & $\begin{array}{l}\text { Preços têm grande } \\
\text { elevação }\end{array}$ \\
\hline
\end{tabular}

\section{Quadro 12 - Estados futuros das variáveis}

Fonte: o autor 


\section{Identificação de temas motrizes dos cenários}

Devem ser definidos temas distintos para cada cenário, nesse caso com as seguintes características: um cenário mais provável que considera as forças históricas continuando a agir como no passado; dois cenários exploratórios contrastados que consideram o desenvolvimento de temas ou eventos marcantes, direcionadores do ambiente futuro; e um cenário normativo. De caráter prescritivo, esse cenário deve apresentar uma situação factível e desejada.

Para a definição do tema dos cenários, levou-se em consideração duas incertezas principais: até que ponto o mercado internacional se expandirá? Quão rápida será a capacitação tecnológica dos players?

- Cenário 1 - Etanol: um biocombustível comercialmente viável

- Cenário 2 - Etanol: a commodity energética global sustentável

- Cenário 3 - Etanol: foco no mercado interno

- Cenário 4 - Etanol: uma commodity regional

\section{Montagem de uma matriz morfológica para cada cenário}

A matriz morfológica é utilizada para combinar de maneira consistente os estados futuros previstos para cada variável dos cenários, com base na estrutura dessas variáveis. 


\begin{tabular}{|c|c|c|c|c|}
\hline & Cenário 1 & Cenário 2 & Cenário 3 & Cenário 4 \\
\hline $\begin{array}{c}\text { Regulamentação } \\
\text { interna dos } \\
\text { países }\end{array}$ & $\begin{array}{c}\text { Mantém tendência } \\
\text { de adição } \\
\text { mandatória }\end{array}$ & $\begin{array}{c}\text { Adição mandatória } \\
\text { aumenta }\end{array}$ & $\begin{array}{l}\text { Adição mandatória } \\
\text { é reduzida }\end{array}$ & $\begin{array}{l}\text { Adição mandatória } \\
\text { tem pequena elevação }\end{array}$ \\
\hline $\begin{array}{c}\text { Capacitação } \\
\text { tecnológica para } \\
\text { produção de } \\
\text { etanol }\end{array}$ & $\begin{array}{c}\text { Capacitação } \\
\text { tecnológica se } \\
\text { mantém nos níveis } \\
\text { atuais }\end{array}$ & $\begin{array}{l}\text { Brasil e Estados } \\
\text { Unidos lideram a } \\
\text { capacitação } \\
\text { tecnológica }\end{array}$ & $\begin{array}{l}\text { Brasil mantém } \\
\text { investimentos para } \\
\text { capacitação } \\
\text { tecnológica }\end{array}$ & $\begin{array}{c}\text { Existência de acordos } \\
\text { entre parceiros } \\
\text { comerciais para } \\
\text { transferência de } \\
\text { tecnologia }\end{array}$ \\
\hline $\begin{array}{l}\text { Estabelecimento } \\
\text { de um padrão } \\
\text { internacional } \\
\text { para o produto }\end{array}$ & $\begin{array}{c}\text { Países estabelecem } \\
\text { padrões para } \\
\text { determinadas } \\
\text { características, } \\
\text { mas as } \\
\text { negociações } \\
\text { continuam }\end{array}$ & $\begin{array}{l}\text { Estabelecimento de } \\
\text { um padrão único }\end{array}$ & $\begin{array}{l}\text { Países não chegam } \\
\text { a um acordo sobre } \\
\text { o estabelecimento } \\
\text { de um padrão }\end{array}$ & $\begin{array}{l}\text { Estabelecimento de } \\
\text { um padrão entre } \\
\text { parceiros comerciais }\end{array}$ \\
\hline $\begin{array}{c}\text { Política } \\
\text { comercial dos } \\
\text { países }\end{array}$ & $\begin{array}{l}\text { Países mantêm } \\
\text { barreiras nos } \\
\text { patamares atuais }\end{array}$ & $\begin{array}{l}\text { Países reduzem } \\
\text { barreiras tarifárias } \\
\text { e não tarifárias }\end{array}$ & $\begin{array}{l}\text { Países aumentam } \\
\text { barreiras tarifárias } \\
\text { e não tarifárias }\end{array}$ & $\begin{array}{c}\text { Países aumentam } \\
\text { moderadamente } \\
\text { barreiras tarifárias e } \\
\text { não tarifárias }\end{array}$ \\
\hline $\begin{array}{c}\text { Movimentos } \\
\text { contrários aos } \\
\text { biocombustíveis }\end{array}$ & $\begin{array}{l}\text { Países encontram } \\
\text { instabilidade na } \\
\text { oferta de alimentos } \\
\text { e biocombustíveis }\end{array}$ & $\begin{array}{l}\text { Países conseguem } \\
\text { produzir } \\
\text { harmonicamente } \\
\text { alimentos e } \\
\text { biocombustíveis }\end{array}$ & $\begin{array}{l}\text { Há preponderância } \\
\text { da produção de } \\
\text { alimentos sobre } \\
\text { biocombustíveis }\end{array}$ & $\begin{array}{l}\text { Há preponderância de } \\
\text { produção de } \\
\text { biocombustíveis sobre } \\
\text { alimentos }\end{array}$ \\
\hline $\begin{array}{l}\text { Desenvolvimento } \\
\text { tecnológico na } \\
\text { indústria } \\
\text { automobilística }\end{array}$ & $\begin{array}{l}\text { Carros flex fuel } \\
\text { mantém tendência } \\
\text { de aprimoramento }\end{array}$ & $\begin{array}{l}\text { Há inovações } \\
\text { elevadas na } \\
\text { tecnologia flex fuel }\end{array}$ & $\begin{array}{l}\text { Outras tecnologias } \\
\text { ganham } \\
\text { preponderância } \\
\text { sobre carros flex } \\
\text { fuel }\end{array}$ & $\begin{array}{l}\text { Há desenvolvimento } \\
\text { moderado na } \\
\text { tecnologia flex fuel }\end{array}$ \\
\hline $\begin{array}{l}\text { Desenvolvimento } \\
\text { tecnológico em } \\
\text { outras indústrias } \\
\text { de transporte }\end{array}$ & $\begin{array}{l}\text { Desenvolvimento } \\
\text { tecnológico } \\
\text { mantém os } \\
\text { patamares atuais }\end{array}$ & $\begin{array}{l}\text { Há grande } \\
\text { desenvolvimento } \\
\text { tecnológico }\end{array}$ & $\begin{array}{l}\text { Há estagnação do } \\
\text { desenvolvimento } \\
\text { tecnológico }\end{array}$ & $\begin{array}{l}\text { Desenvolvimento } \\
\text { tecnológico ocorre de } \\
\text { forma moderada }\end{array}$ \\
\hline $\begin{array}{c}\text { Preços } \\
\text { internacionais } \\
\text { do petróleo }\end{array}$ & $\begin{array}{l}\text { Preço mantém os } \\
\text { patamares atuais }\end{array}$ & $\begin{array}{l}\text { Preços têm grande } \\
\text { elevação }\end{array}$ & Preços caem & $\begin{array}{c}\text { Preços têm pequena } \\
\text { elevação }\end{array}$ \\
\hline $\begin{array}{c}\text { Preços } \\
\text { internacionais } \\
\text { do açúcar }\end{array}$ & $\begin{array}{l}\text { Preço mantém os } \\
\text { patamares atuais }\end{array}$ & Preços caem & $\begin{array}{l}\text { Preços têm grande } \\
\text { elevação }\end{array}$ & $\begin{array}{c}\text { Preços têm pequena } \\
\text { elevação }\end{array}$ \\
\hline
\end{tabular}

\section{Quadro 13 - Matriz morfológica dos cenários}

Fonte: o autor

\section{Redação e validação dos cenários}

O detalhamento dos cenários, com a descrição de sua evolução e a explicitação das relações e seqüências de causa e efeito entre as variáveis consideradas, assim como análise da consistência interna, da plausibilidade de cada cenário e da relevância das variáveis dos cenários para as decisões a serem tomadas; e a validação dos cenários com especialistas ou 
grupos de interesse, por meio da apresentação e discussão destes; é a etapa final de elaboração.

Assim, como resultado do processo, chegou-se aos cenários que serão descritos abaixo.

\section{Cenário 1 - Etanol: um biocombustível comercialmente viável}

É 2020 e o mercado internacional de etanol atingiu as estimativas baseadas na adição mandatória do produto à gasolina.

Avanços tecnológicos em relação à ampliação do uso do etanol como combustível não foram adotados em larga escala na indústria. Entretanto, a tecnologia flex fuel dá sinais de penetração em diversos países.

As tecnologias comercialmente viáveis ainda são baseadas no etanol de $1^{\text {a }}$ geração. Muitos países ainda utilizam políticas de subsídios a produtores internos e tarifas de importação para proteger seus mercados, o que desestimula a inovação.

As negociações sobre o comércio internacional de etanol entram com vigor na pauta das rodadas da $\mathrm{OMC}$, mas ainda não há acordos conclusivos para a liberalização do comércio.

Há um padrão estabelecido para o produto no mercado internacional e os países têm realizado esforços contínuos para se capacitarem e atenderem às especificações.

\section{Cenário 2 - Etanol: a commodity energética global sustentável}

É 2020 e o comércio internacional de etanol está bem estabelecido e apresenta grande dinamismo. Diversos países importantes cumpriram as metas de adição mandatória de etanol à gasolina e há perspectivas de aumento ainda maior do mercado com a introdução e penetração da tecnologia flex fuel em seus mercados automobilísticos.

$\mathrm{O}$ etanol de $2^{\mathrm{a}}$ geração tornou-se uma realidade e tem possibilitado ganhos de produtividade e redução de custos. Outros usos do etanol como combustível têm ganhado mercado. 
Os países têm buscado estabelecer acordos multilaterais para produção e fornecimento de etanol, envolvendo a diminuição da tarifação para entrada nesses mercados.

O estabelecimento de um padrão mundial para o produto, entretanto, tem limitado o acesso de países menos desenvolvidos em termos de tecnologia e capacitação para produção do combustível.

\section{Cenário 3 - Etanol: foco no mercado interno}

É 2020 e o etanol é produzido e consumido no mercado dos próprios países que adotaram o biocombustível.

O não-entendimento entre os países para o estabelecimento de um padrão internacional e as políticas protecionistas - principalmente subsídios aos produtores locais e tarifas para importação - enfatizam o mercado local como alternativa de ganhos econômicos com a produção do biocombustível.

O etanol de $2^{\mathrm{a}}$ geração ainda não é comercialmente viável e a tecnologia flex fuel é restrita a um número pequeno de países. Não há avanços concretos na diversificação e ampliação do uso do etanol como combustível.

\section{Cenário 4 - Etanol: uma commodity regional}

É 2020 e o comércio internacional de etanol é feito de forma regionalizada, resultado de acordos bilaterais ou entre blocos regionais de países.

A tecnologia de etanol de $2^{\mathrm{a}}$ geração é uma realidade comercial dominada por poucos players do mercado. A tecnologia flex fuel é introduzida em determinados países como parte dos acordos bilaterais para produção e fornecimento do produto, onde os governos oferecem incentivos para a indústria automobilística.

Não há um padrão internacional e as especificações do produto são resultados de entendimentos específicos entre países. A aplicação do etanol como combustível é uma frente 
de pesquisa que continua a ser desenvolvida em países que adotaram o produto, buscando-se ampliar as possibilidades de utilização.

\subsection{Estudo empírico: aplicação dos cenários, atuação e capacidades dinâmicas}

\subsubsection{A empresa}

A Usina Dacalda Açúcar e Álcool iniciou suas atividades em 1964 quando Homero Corrêa de Arruda adquiriu a propriedade rural denominada Fazenda Santa Maria, na cidade de Jacarezinho - Paraná. Com 200 alqueires, a fazenda tinha como atividades a pecuária de corte, criação de eqüinos e suínos, cultivo de algodão, milho, soja, arroz, feijão, alfafa e café. A cana-de-açúcar era somente cultivada para alimentação dos animais. Em 1969, com perspectiva de ampliar a propriedade, foram adquiridas também as fazendas São Fernando e Água do Peixe, adjacentes à Fazenda Santa Maria.

Em conjunto com todas as atividades, as fazendas tornam-se também fornecedoras de mudas selecionadas de cana-de-açúcar para grande parte do Paraná. No ano de 1970, em uma iniciativa empreendedora é fundada a Corrêa de Arruda Indústria e Comércio de Aguardente Ltda. Em 1980, através dos incentivos oferecidos pelo Pró-Álcool, é implantada a Destilaria Corrêa de Arruda Ltda - DACALDA. A primeira safra teve inicio em 1981 com a produção de 3.079.850 litros de álcool.

No ano de 1994 inicia-se uma nova fase da empresa sob o comando de Constante Ometto Corrêa de Arruda e Sérgio Roberto Fioravante. A partir de 2000, a empresa iniciou investimentos com objetivo de aumentar a capacidade de produção para atender a demanda do mercado. Atualmente, a empresa administra uma área agrícola de aproximadamente 6.000 ha de cana própria e 5.000 ha de fornecedores, localizadas nos municípios de Andirá, Barra do Jacaré, Santo Antonio Platina, Jacarezinho e Cambará. Totalizando produção de um milhão de toneladas de cana por ano. A capacidade diária de produção de álcool é de 450 mil litros. Por safra, a produção de álcool é de 79 milhões de litros. 


\subsubsection{Visão de futuro, atuação e capacidades dinâmicas}

Foram apresentados para o dirigente da empresa os quatro cenários elaborados neste trabalho, que foram considerados todos plausíveis e internamente consistentes. Foi indicado como mais provável o cenário "Etanol: a commodity energética global sustentável”. Entretanto, foi ressaltado diversas vezes que há ceticismo quanto à utilidade de visões do mercado para daqui a 10 anos. Isso porque há preocupações com a sobrevivência da empresa no curto prazo, dada a grande volatilidade do mercado atualmente.

Em 2000, a empresa iniciou a exportação de etanol, tendo como primeiro mercado países da União Européia. Em seguida, a empresa também passou a atuar nos Estados Unidos via Caribe - para onde envia-se inicialmente etanol desidratado e faz-se a hidratação, tendo em vista alcançar o mercado americano com menos tributos. $\mathrm{O}$ volume de exportação atual da empresa é de cerca de $15 \%$ da produção.

Para atingir o mercado externo, a empresa atua junto a Bioagência - empresa independente localizada na cidade de São Paulo que atua como um canal de comercialização dos produtos de seus associados. Como para alcançar competitividade e conseguir contratos é necessário um certo volume de etanol que sozinha a empresa não conseguiria atingir, ela tem na Bioagência um meio que possibilita a venda conjunta com outros associados viabilizando negócios.

Para a empresa, a incerteza em relação a preços do etanol é grande, o que dificulta um comprometimento firme com o mercado externo. A empresa atua no sentido de aproveitar as oportunidades pontuais. O fato de a empresa ter uma boa posição financeira, que suporta turbulências, possibilita que a empresa possa atuar e fazer frente aos riscos e incertezas de atuação no mercado externo.

Desde que iniciou as exportações, a empresa criou uma área de controle de qualidade para assegurar o padrão do produto para o cliente. Isso envolveu a aquisição de ativos para o laboratório e contratação e treinamento de mão-de-obra especializada. Além disso, houve uma expansão da estrutura de vendas. 
Para a identificação de novas oportunidades de negócios, a empresa participa de uma reunião semanal na Bioagência, ocasião na qual é discutido o panorama do setor e as perspectivas para o futuro. Identificada uma oportunidade de exportação, nessas reuniões a empresa se articula com os outros produtores participantes para capturá-la. Assim, as reuniões na Bioagência servem de fonte de informação de mercado (inteligência de mercado) que alimenta o sistema da empresa. A estrutura da Bioagência permite a padronização dos contratos de exportação e ganhos de volume. A formação de tais relacionamentos por meio da Bioagência é uma alternativa para competir em um contexto de concentração do setor, onde grandes grupos empresariais estão sendo formados e pressionando as usinas independentes. Assim, é importante para competir no mercado a atuação conjunta com os associados da Bioagência uma vez que há uma pulverização dos produtores independentes e uma concentração dos compradores.

Além da participação na Bioagência, a empresa tem parceria com o Centro de Tecnologia Canavieira - CTC. Tal parceria ocorre da seguinte forma: o CTC faz um índice de indicadores de desempenho de inovação e plota as empresas associadas em um gráfico para mostrar a sua posição. Com base nessa informação, a empresa identifica a sua demanda por projetos de Pesquisa e Desenvolvimento $(P \& D)$. Portanto, a empresa não realiza atividades de $P \& D$ internamente. As atividades são realizadas por meios de acordos de cooperação externa com o CTC, que envolvem pesquisas nas áreas de etanol de segunda geração, métodos industriais e variedades agrícolas.

$\mathrm{Na}$ visão da empresa, o ambiente institucional brasileiro para o setor de etanol é favorável, haja vista os estímulos governamentais para a fabricação do biocombustível e a existência de instituições pró-etanol.

Nos próximos anos, as principais inovações que devem afetar o setor é o desenvolvimento de biocombustíveis de fontes que não sejam alimentos, ou seja, o desenvolvimento de outras biomassas, como algas. Além disso, a eletricidade como fonte de combustível para veículos deve ser acompanhada.

No futuro, segundo a empresa pesquisada, será necessário desenvolver um novo modelo de negócios para as usinas, pois essas são muito suscetíveis às oscilações de mercado de curto prazo, principalmente em relação ao preço do álcool, preço do açúcar, preço do petróleo e 
preço do milho. Há a necessidade de novas fontes de receita nos períodos de baixa no mercado.

A empresa enxerga como grande obstáculo para o futuro o desenvolvimento de infra-estrutura logística para a exportação. A estrutura atual não suporta o aumento. Isso revela a necessidade de ativos complementares para o aproveitamento de novas oportunidades de negócios.

No que se refere ao desenvolvimento de alcooldutos são os diferentes padrões de etanol existentes atualmente, pois há a necessidade de comprometimento de ativos para uma única finalidade.

Teece, Pisano e Shuen (1997) sintetizam que a essência da competência e das capacidades dinâmicas de uma empresa residem em seus processos organizacionais, que são moldados por seus ativos (posição de ativos) e sua trajetória evolucionária. Em desenvolvimento posterior da teoria, Teece (2007) afirma que as capacidades dinâmicas de uma firma estão relacionadas a três macro-processos - perceber e moldar oportunidades e ameaças, capturar oportunidades e combinar, reconfigurar e proteger ativos.

Considerando a abordagem de cenários, inicialmente buscou-se aplicá-los para analisar a percepção de ambiente da empresa, estando essa relacionada com o grupo de capacidades de perceber e moldar oportunidades e ameaças. Segundo Teece (2007), esta capacidade envolve atividades para escanear, criar, aprender e interpretar novas oportunidades. Os processos que possibilitam tais atividades estão relacionados à capacidade da empresa dirigir Pesquisa e Desenvolvimento interno para selecionar novas tecnologias, selecionar inovação de fornecedores e complementadores, selecionar desenvolvimento exógeno em Ciência e Tecnologia, e identificar segmentos de mercados-alvo, necessidades de consumidores em mutação e inovação.

Aplicando o conceito de capacidades dinâmicas para analisar o caso, depreende-se que a empresa estudada busca desenvolver os processos para selecionar desenvolvimento exógeno em Ciência e Tecnologia por meio do convênio com o Centro de Tecnologia Canavieira, sendo esta, portanto, uma capacidade identificada. 
Além disso, outro ponto marcante refere-se às atividades para identificar segmentos de mercados-alvo, necessidades de consumidores em mutação e inovação. Na empresa pesquisada, ganha importância a participação na Bioagência, principal fonte de informação de mercado, a partir da qual oportunidades são identificadas.

Segundo Teece (2007), perceber e moldar oportunidades de negócios envolve atividades de escaneamento, criação, aprendizagem e interpretação. Investimento em pesquisa e em atividades relacionadas usualmente são complementos necessários a essas atividades.

Pode-se inferir no caso estudado que a empresa busca desenvolver capacidades para identificar e moldar oportunidades. Para o futuro, o desafio será desenvolver as capacidades necessárias para capturar as oportunidades e dois pontos importantes foram destacados pela empresa, e que vão de encontro ao segundo grupo de capacidades propostas por Teece (2007), principalmente no que se refere ao delineamento de modelos de negócios e desenvolvimento de ativos complementares.

Conforme foi destacado pelo dirigente durante a entrevista, será necessário desenvolver um novo modelo de negócios para as usinas, pois essas são muito suscetíveis às oscilações de mercado de curto prazo, principalmente em relação ao preço do álcool, preço do açúcar, preço do petróleo e preço do milho. Há a necessidade de novas fontes de receita nos períodos de baixa no mercado. Além disso, a empresa enxerga como grande obstáculo para o futuro o desenvolvimento de infra-estrutura logística para a exportação. A estrutura atual não suporta o aumento.

Para Teece (2007), a função de um modelo de negócios é articular a proposição de valor, selecionar a tecnologia apropriada, identificar segmentos-alvo de mercado, definir a estrutura da cadeia de valor e estimar a estrutura de custos e os lucros potenciais. Nas usinas de etanol, a capacidade dinâmica residirá no aperfeiçoamento de biorefinarias, agregando outras fontes de receitas a partir da exploração de subprodutos do processo de produção de etanol, como a bioeletricidade. 


\section{CONSIDERAÇÕES FINAIS}

Este trabalho teve os seguintes objetivos: descrever o cenário atual do mercado internacional de etanol; elaborar quatro cenários futuros possíveis para o mercado internacional em 2020; e analisar empiricamente a consistência dos cenários e seus desdobramentos para o desenvolvimento de capacidades dinâmicas.

Em relação ao primeiro objetivo, constatou-se que há a percepção de grandes oportunidades para o estabelecimento de um mercado internacional para o etanol, tendo destaque o mercado dos Estados Unidos e da união Européia no ponto de vista das exportações do Brasil.

Em relação ao segundo objetivo, utilizou-se o método de elaboração de cenários proposto por Wright e Spers (2006), que tomou por base a contextualização do cenário atual do mercado internacional de etanol feita a partir de dados primários e secundários. Neste trabalho, o escopo dos cenários foi a configuração futura do mercado internacional de etanol. O horizonte de tempo foi 2020, uma vez que grande parte da regulamentação que indica expansão da demanda do mercado internacional baseia-se neste ano. Foram produzidos quatro cenários ("Etanol: um biocombustível comercialmente viável”, "Etanol: a commodity energética global sustentável", "Etanol: foco no mercado interno", e "Etanol: uma commodity regional") que posteriormente foram submetidos à análise de consistência e indicação do mais provável pela empresa pesquisa neste estudo. Foi indicado como mais provável o cenário "Etanol: a commodity energética global sustentável”. Entretanto, foi ressaltado diversas vezes que há ceticismo quanto a visões para o mercado em 10 anos. Isso porque há preocupações com a sobrevivência da empresa no curto prazo, dada a grande volatilidade do mercado atualmente.

A partir do cenário mais provável, a empresa pesquisada indicou que, para o futuro, o desafio será desenvolver as capacidades dinâmicas necessárias para capturar as oportunidades e dois pontos importantes foram destacados pela empresa, e que vão de encontro ao segundo grupo de capacidades propostas por Teece (2007), principalmente no que se refere ao delineamento de modelos de negócios e desenvolvimento de ativos complementares.

Conforme foi destacado pelo dirigente durante a entrevista, será necessário desenvolver um novo modelo de negócios para as usinas, pois essas são muito suscetíveis às oscilações de mercado de curto prazo, principalmente em relação ao preço do álcool, preço do açúcar, preço 
do petróleo e preço do milho. Há a necessidade de novas fontes de receita nos períodos de baixa no mercado. Além disso, a empresa enxerga como grande obstáculo para o futuro o desenvolvimento de infra-estrutura logística para a exportação. A estrutura atual não suporta o aumento. Fica bastante claro da análise do caso que a utilização de cenários é uma forma importante de ajudar a pensar o futuro da organização e estruturar o desenvolvimento das capacidades dinâmicas necessárias para manter a competitividade futura da empresa analisada.

É importante destacar que esse trabalho é de natureza exploratória. Trabalhos futuros poderão explorar cenários em uma abordagem qualitativa e quantitativa, além de aprofundar o estudo das capacidades dinâmicas no contexto da indústria de etanol, elaborando e propondo um modelo de desenvolvimento de capacidades que permitam que o conjunto das usinas brasileiras possam se manter competitivas no futuro. 


\section{REFERÊNCIAS BIBLIOGRÁFICAS}

AGROANALYSIS. Agenda Brasil-EUA. Revista Agroanalysis (FGV). V.27, n.03, mar. 2007, p.23.

BACCHI, M.R.P.; CABRINI, M. De F.; MARJOTTA-MAISTRO, M.C. Panorama internacional. Revista Agroanalysis (FGV). V.27, n.02, fev. 2007, p.36.

BANCO NACIONAL DE DESENVOLVIMENTO ECONÔMICO E SOCIAL - BNDES. Bioetanol de cana-de-açúcar - energia para o desenvolvimento sustentável. 2008.

Disponível em: <http://www.bioetanoldecana.org/pt/download/bioetanol.pdf>. Acesso em: 13 jan. 2009.

BARDIN, L. Análise de conteúdo. Lisboa: Edições 70, 1979. 230 p.

BARROS, A.M. de; FAULIN, E.J.; PICCHETTI, P.; PEROSA, R. O impacto dos biocombustíveis. Revista Agroanalysis (FGV). V.28, n.11, nov. 2008, p.40-42.

BASTOS, V.D. Etanol, alcoolquímicas e biorrefinarias. BNDES Setorial. 2007. Disponível em:

<http://www.bndespar.gov.br/SiteBNDES/export/sites/default/bndes_pt/Galerias/Arquivos/co nhecimento/bnset/set2501.pdf>. Acesso em: 13 jan. 2009.

BOAVENTURA, J. M. G.; COSTA, B. K.; FISCHMANN, A. A. Cenários: metodologias e métodos de construção. In: COSTA, B. K.; ALMEIDA, M. I. R. de (org.) Estratégia Direcionando negócios e organizações. São Paulo: Atlas, 2005 p. 23-43.

COATES, J. F. Scenario planning. Technological Forecasting and Social Change. V. 65, n. 1, set. 2000. p.115-123.

COLLIS, J.; HUSSEY, R. Pesquisa em Administração. Porto Alegre: Bookman, 2005. 352 p.

COOPER, D. R; SCHINDLER, S. P. Métodos de Pesquisa em Administração. 7.ed. Porto Alegre: Bookman, 2003. 640p.

COSTA, R.C. da; PRATES, C.P.T. O papel das fontes renováveis de energia no desenvolvimento do setor energético e barreiras à sua penetração no mercado. BNDES Setorial. 2005. Disponível em:

<http://www.bndes.gov.br/SiteBNDES/export/sites/default/bndes_pt/Galerias/Arquivos/conhe cimento/bnset/set2102.pdf>. Acesso em: 13 jan. 2009.

DEPARTAMENTO DE PROSPECÇÃO E PLANEJAMENTO DE PORTUGAL. Prospecção e cenários - uma breve introdução metodológica. Lisboa: Departamento de prospecção e Planejamento, 1997.

EISENHARDT, K. M.; MARTIN, J.A. Dynamic capabilities: what are they? Strategic Management Journal. V. 21, 2000, p.1105-1121. 
EMPRESA DE PLANEJAMENTO ENERGÉTICO - EPE. Perspectivas para o etanol no Brasil. 2008. Disponível em:

<http://www.epe.gov.br/Petroleo/Documents/Estudos_28/Cadernos\%20de\%20Energia\%20$\% 20$ Perspectiva\%20para\%20o\%20etanol\%20no\%20Brasil.pdf $>$. Acesso em: 08 mar. 2009.

FAHEY, L.; RANDALL, R.M. Learning from the future - competitive foresight scenarios. New York: Wiley, 1998. 464 p.

GIL, A.C. Como elaborar projetos de pesquisa. São Paulo: Atlas, 2009. 175 p.

GODET, M. The art of scenarios and strategic planning: tools and pitfalls. Technological Forecasting and Social Change. V. 65, n. 1, set. 2000. p. 3-22.

GOLDEMBERG, J.; MOREIRA, J.R. Política energética no Brasil. Estudos Avançados. V.55, n.19, set.-dez. 2005, p. 215-228.

HUSS, W. R. A move toward scenario analysis. International Journal of Forecasting. V.4, n.3, 1988. p. 377-388.

JOUVENEL, H. de A brief methodological guide to scenario building. Technological Forecasting and Social Change. V. 65, n. 1, set. 2000. p. 37-48.

KUTAS, G.; ZECHIN, M.R. Em busca da globalização. Revista Agroanalysis (FGV). V.28, n.08, ago. 2008, p.25-28.

MASINI, E.; VASQUEZ, J. Scenarios as seen from a human and social perspective. Technological Forecasting \& Social Change. V. 65, n. 1, set. 2000. p.49-66.

MILANEZ, A.Y.; FAVARET FILHO, P. de S. C.; ROSA, S.E.S. da Perspectivas para o etanol brasileiro. BNDES Setorial. 2008. Disponível em:

<http://www.bndes.gov.br/SiteBNDES/export/sites/default/bndes_pt/Galerias/Arquivos/conhe cimento/bnset/set2702.pdf>. Acesso em: 14 jan. 2009.

MINISTÉRIO DA AGRICULTURA, PECUÁRIA E ABASTECIMENTO - MAPA. Relação das Unidades Produtoras Cadastradas no Departamento da Cana-de-açúcar e Agroenergia. 2009. Disponível em: <http://www.mapa.gov.br. Acesso em: 03 jul. 2009.

RICHARDSON, R.J. Pesquisa social - métodos e técnicas. São Paulo: Atlas, 2009. 334 p.

RODRIGUES, A. de P.; RODRIGUES, L. O etanol e os desafios do mercado interno.

Revista Agroanalysis (FGV). V.28, n.08, ago. 2008, p.22-24.

SACHS, I. Da civilização do petróleo a uma nova civilização verde. Estudos Avançados. V.55, n.19, set.-dez. 2005, p. 196-214.

SCHNAARS, S.P.; TOPOL, M.T. The use of multiple scenarios in sales forecasting. International Journal of Forecasting. V. 3, n. 3-4, 1987. p. 405-419.

SCHOEMAKER, P. J. H. Scenario Planning: A Tool for Strategic Thinking. Sloan

Management Review. Winter 1995. p. 25-40. 
SELLTIZ, C.; WRIGHTSMAN, L.S.; COOK, S. W. Métodos de pesquisa nas relações sociais. São Paulo, Epu, 2004.

SILVA, JR. Etanol: garantindo a qualidade para os mercados. Revista Agroanalysis (FGV). V.28, n.08, ago. 2008, p.29-31.

SZWARC, A. Ninguém é líder por acaso. Revista Agroanalysis (FGV). V.28, n.08, ago. 2008, p.24-25.

TEECE, D.J. Explicating dynamic capabilities: the nature and microfoundations of (sustainable) enterprise performance. Strategic Management Journal. V. 28, 2007, p. 13191350 .

TEECE, D.J.; PISANO, G.; SHUEN, A. Dynamic capabilities and strategic management. Strategic Management Journal. V. 18, n. 07, 1997, p. 509-533.

TIMOSSIL, A.J. Resistência européia. Revista Agroanalysis (FGV). V.28, n.05, mai. 2008, p.37-38.

UNIÃO DA INDÚSTRIA DE CANA-DE-AÇÚCAR - UNICA. Internacionalização do etanol. Revista Agroanalysis (FGV). V.27, n.05, mai. 2007a, p. E3-E4.

UNIÃO DA INDÚSTRIA DE CANA-DE-AÇÚCAR - UNICA. Consolidação internacional. Revista Agroanalysis (FGV). V.27, n.05, mai. 2007b, p. E10.

UNIÃO DA INDÚSTRIA DE CANA-DE-AÇÚCAR - UNICA. Consolidação internacional. Revista Agroanalysis (FGV). V.27, n.05, mai. 2007c, p. E20-E21.

VASCONCELOS, F.C.; CYRINO, A.B. Vantagem competitiva: os modelos teóricos atuais e a convergência entre estratégia e teoria organizacional. Revista de Administração de Empresas. V.40, n.04, out.-dez. 2000, p. 20-37.

VOLBERDA, H. W. Crise em estratégia: fragmentação, integração ou síntese. Revista de Administração de Empresas. V. 44, n. 4, out.- dez. 2004. p.32-43.

WRIGHT, J.T.C.; SPERS, R. G. O país no futuro: aspectos metodológicos e cenários. Estudos Avançados. V. 20, n. 56, jan.-abr. 2006. p. 13-28.

YIN, R. K. Estudo de caso: planejamento e métodos. Porto Alegre: Bookman, 2005.

ZAHRA, S.A.; SAPIENZA, H. J.; DAVIDSSON, P. Entrepreneurship and dynamic capabilities: a review, model and research agenda. Journal of Management Studies. V. 43, n.04. jun. 2006, p. 917-955. 


\section{ANEXOS \\ ANEXO 1 \\ Roteiro de entrevista - UNICA}

1. Como o senhor enxerga a possibilidade a possível formação de um mercado internacional de etanol nos próximos 10 anos?

2. Quais os fatores que potencializam a expansão do mercado?

3. Quais os fatores que inibem a expansão do mercado?

4. Como o senhor percebe o desenvolvimento das tecnologias para produção de etanol nos próximos 10 anos?

5. Qual é o estágio atual das pesquisas de aplicações do etanol? Há fronteiras com perspectivas interessantes de novos usos do etanol?

6. Quais as perspectivas para a introdução da tecnologia flex-fuel em outros países nos próximos 10 anos?

7. Como as destilarias brasileiras pretendem se posicionar no mercado internacional?

8. Quais são os mercados mais atrativos para o etanol brasileiro? Por quê?

9. Como o senhor vê a atuação dos principais players (EUA, União Européia, Índia e China) nos próximos 10 anos?

10. Quais países têm condições mais interessantes para entrar no mercado como fornecedores do produto? E como consumidores?

11. Quais são os principais desafios para as destilarias brasileiras expandirem as exportações nos próximos 10 anos?

12. Na sua opinião, quais as possíveis alianças mais promissoras que países poderão formar para o estabelecimento de um mercado internacional de etanol nos próximos 10 anos? 


\section{ANEXO 2 \\ Roteiro de Entrevista - DaCalda}

1. Quando a empresa iniciou a produção de etanol? Como foi esse processo?

2. Para quais mercados a empresa comercializou inicialmente? E hoje? Quais são os mercados?

3. Qual é a importância do mercado externo para a empresa?

4. Como a empresa enxerga as perspectivas futuras para atuação no mercado externo?

5. Como a empresa avalia a sua posição competitiva em relação aos players dos seus mercados de exportação?

6. Desde que começou a exportar, quais áreas da empresa mais sofreram mudanças?

7. Quais foram os principais motivadores das mudanças?

8. Quais os principais recursos que tiveram que ser desenvolvidos? Como foi esse processo?

9. Houve alterações na estrutura organizacional? Como isso ocorreu?

10. Na empresa, quais são os principais processos envolvidos na identificação de novas oportunidades de negócios? Quais áreas participam?

11. A empresa possui atividades internas de Pesquisa e Desenvolvimento? Se sim, para quais linhas de pesquisa? Quais as principais atividades envolvidas?

12. A empresa já estabeleceu acordos externos para realização de Pesquisa e Desenvolvimento? Se sim, para quais linhas de pesquisa? Quais as principais atividades envolvidas?

13. Como a empresa avalia o movimento de formação de grupos empresariais para a produção de etanol?

14. A empresa já estabeleceu alguma forma de associação com outros participantes da cadeia produtiva? Como foi esse processo?

15. Como você avalia o nosso ambiente institucional no que tange a competitividade do etanol brasileiro no exterior?

16. Na sua opinião, quais são as principais inovações que devem afetar a dinâmica competitiva do mercado internacional de etanol?

17. Considere os cenários para o comércio internacional de etanol em 2020 apresentados abaixo. Qual você considera o mais provável? 
18. Para o cenário mais provável, quais são os recursos críticos que as usinas terão que desenvolver para se manterem competitivas? E a sua usina especificamente?

19. Quais processos organizacionais já existentes na empresa seriam envolvidos?

20. Quais processos que na sua opinião a empresa teria que desenvolver?

21. Quais serão os principais facilitadores internos para a empresa desenvolver os recursos críticos e os processos organizacionais necessários?

22. Quais serão os principais desafios internos para a empresa desenvolver os recursos críticos e os processos organizacionais necessários?

\begin{tabular}{|c|c|}
\hline $\begin{array}{l}\text { A-Etanol: um biocombustível comercialmente viável } \\
\text { É } 2020 \text { e o mercado internacional de etanol atingiu as } \\
\text { estimativas baseadas na adição mandatória do produto à } \\
\text { gasolina. Avanços tecnológicos em relação à ampliação } \\
\text { do uso do etanol como combustível não foram adotados } \\
\text { em larga escala na indústria. Entretanto, a tecnologia } \\
\text { flex-fuel dá sinais de penetração em diversos países. As } \\
\text { tecnologias comercialmente viáveis ainda são baseadas } \\
\text { no etanol de } 1^{\text {a }} \text { geração. Muitos Países ainda utilizam } \\
\text { políticas de subsídios a produtores internos e tarifas de } \\
\text { importação para proteger seus mercados, o que } \\
\text { desestimula a inovação. As negociações sobre o } \\
\text { comércio internacional de etanol entram com vigor na } \\
\text { pauta das rodadas da OMC, mas ainda não há acordos } \\
\text { conclusivos para a liberalização do comércio. Há um } \\
\text { padrão estabelecido para o produto no mercado } \\
\text { internacional e os países têm realizado esforços } \\
\text { contínuos para se capacitarem e atenderem às } \\
\text { especificações. }\end{array}$ & $\begin{array}{l}\text { B-Etanol: a commodity energética global sustentável } \\
\text { É } 2020 \text { e o comércio internacional de etanol está estabelecido } \\
\text { e apresenta grande dinamismo. Diversos países importantes } \\
\text { cumpriram as metas de adição mandatória de etanol à } \\
\text { gasolina e há perspectivas de aumento ainda maior do } \\
\text { mercado com a introdução e penetração da tecnologia flex- } \\
\text { fuel em seus mercados automobilísticos. O etanol de } 2^{\text {a }} \\
\text { geração tornou-se uma realidade e tem possibilitado ganhos } \\
\text { de produtividade e redução de custos. Outros usos do etanol } \\
\text { como combustível têm ganhado mercado. Os países têm } \\
\text { buscado estabelecer acordos multilaterais para produção e } \\
\text { fornecimento de etanol, envolvendo a diminuição da } \\
\text { tarifação para entrada nesses mercados. O estabelecimento } \\
\text { de um padrão mundial para o produto, entretanto, tem } \\
\text { limitado o acesso de países menos desenvolvidos em termos } \\
\text { de tecnologia e capacitação para produção do combustível. }\end{array}$ \\
\hline $\begin{array}{l}\text { C - Etanol: foco no mercado interno } \\
\text { É } 2020 \text { e o etanol é produzido e consumido no mercado } \\
\text { dos próprios países que adotaram o biocombustível. O } \\
\text { não-entendimento entre os países para o estabelecimento } \\
\text { de um padrão internacional e as políticas protecionistas - } \\
\text { principalmente subsídios aos produtores locais e tarifas } \\
\text { para importação - enfatizam o mercado local como } \\
\text { alternativa de ganhos econômicos com a produção do } \\
\text { biocombustível. O etanol de } 2^{\text {a }} \text { geração ainda não é } \\
\text { comercialmente viável e a tecnologia flex-fuel é restrita } \\
\text { a um número pequeno de países. Não há avanços } \\
\text { concretos na diversificação e ampliação do uso do etanol } \\
\text { como combustível. }\end{array}$ & $\begin{array}{l}\text { D - Etanol: uma commodity regional } \\
\text { É } 2020 \text { e o comércio internacional de etanol é feito de forma } \\
\text { regionalizada, resultado de acordos bilaterais entre países. A } \\
\text { tecnologia de etanol de } 2^{\text {a }} \text { geração é uma realidade comercial } \\
\text { dominada por poucos players do mercado. A tecnologia flex- } \\
\text { fuel é introduzida em determinados países como parte dos } \\
\text { acordos bilaterais para produção e fornecimento do produto, } \\
\text { onde os governos oferecem incentivos para a indústria } \\
\text { automobilística. Não há um padrão internacional e as } \\
\text { especificações do produto são resultados de entendimentos } \\
\text { específicos entre países. A aplicação do etanol como } \\
\text { combustível é uma frente de pesquisa que continua a ser } \\
\text { desenvolvida em países que adotaram o produto, buscando- } \\
\text { se ampliar as possibilidades de utilização. }\end{array}$ \\
\hline
\end{tabular}

